NBER WORKING PAPER SERIES

\title{
ON THE CONNECTIONS BETWEEN INTERTEMPORAL AND INTRA-TEMPORAL TRADES
}

Jiandong Ju

Kang Shi

Shang-Jin Wei

Working Paper 17549

http://www.nber.org/papers/w17549

\author{
NATIONAL BUREAU OF ECONOMIC RESEARCH \\ 1050 Massachusetts Avenue \\ Cambridge, MA 02138 \\ October 2011
}

The paper is a substantial revision of an earlier paper, "Current Account Adjustment: Some New Theory and Evidence." We have replaced the OLG model in the earlier version with an infinity-horizon setup in this version and calibrated the model to study adjustments in both intertemporal trade and intra-temporal trade under technology shocks and preference shocks. We thank Joshua Aizenman, Rudolfs Bems, Richard Clarida, Giancarlo Corsetti, Luca Dedola, Mick Deveraux, Marcel Fratzscher, Gordon Hanson, Jean Imbs, Olivier Jeanne, Aart Kraay, Nuno Limao, Akito Matsumoto, Jonathan Ostry, David Parsley, Ken Rogoff, Eric van Wincoop and seminar/conference participants at Northwestern University, University of Lausanne, Graduate Institute for International Studies in Geneva, the IMF, the European Central Bank, SED Annual Meeting 2008, CEPR Conference on International Macroeconomics and Finance, Paris 2008, and Columbia-Tsinghua Conference on International Economics 2010, and 2013 NBER-CEPR ISOM conference for helpful discussions and suggestions, and Chang Hong, Erik von Uexkull, and Xuebing Yang for very capable research assistance. The views expressed herein are those of the authors and do not necessarily reflect the views of the National Bureau of Economic Research.

NBER working papers are circulated for discussion and comment purposes. They have not been peerreviewed or been subject to the review by the NBER Board of Directors that accompanies official NBER publications.

(C) 2011 by Jiandong Ju, Kang Shi, and Shang-Jin Wei. All rights reserved. Short sections of text, not to exceed two paragraphs, may be quoted without explicit permission provided that full credit, including (C) notice, is given to the source. 
On the Connections between Intertemporal and Intra-temporal Trades

Jiandong Ju, Kang Shi, and Shang-Jin Wei

NBER Working Paper No. 17549

October 2011, Revised December 2013

JEL No. F30,F41

\begin{abstract} of intra-temporal trade into an intertemporal trade approach of current account. To do so, we consider for substitution between intertemporal trade (current account adjustment) and intra-temporal trade the composition of goods trade and a change in the current account. Flexible factor markets reduce larger the size of current account adjustment relative to the volume of goods trade, and the slower the speed of adjustment of the current account towards its long-run equilibrium. We present empirical evidence consistent with the theory.

Jiandong Ju

Tsinghua University

School of Economics and Management

Beijing, China

jdju@ou.edu

Kang Shi

Department of Economics

Chinese University of Hong Kong

Shatin, New Territories

Hong Kong

kangshi@cuhk.edu.hk

Shang-Jin Wei

Graduate School of Business

Columbia University

Uris Hall 619

3022 Broadway

New York, NY 10027-6902

and NBER

shangjin.wei@columbia.edu
\end{abstract}

This paper develops a new theory of international economics by introducing Heckscher-Ohlin features a dynamic general equilibrium model with tradable sectors of different factor intensities, which allows (goods trade). An economy's response to a shock generally involves a combination of a change in the need for the current account to adjust. On the other hand, the more rigid the factor markets, the 


\section{Introduction}

This paper aims to shed some new light on the connection between intertemporal trade (or net foreign borrowing), the usual subject of open-economy macroeconomics, and intra-temporal trade, the usual subject of international trade. The standard open-economy macro models feature either multiple tradable sectors with a common factor intensity or sometimes a single tradable sector. Such models do not feature Heckscher-Ohlin (HO) structure. In contrast, by incorporating a Heckscher-Ohlin (HO) structure into a fully dynamic general equilibrium model and not imposing a balanced trade assumption, we show some novel connections between intra-temporal and intertemporal trade and uncover a natural role of domestic labor market rigidity in current account adjustment patterns.

The intertemporal approach to current account was developed in seminal work by Sachs (1981, 1982) and Svesson and Razin (1983), and codified in Obstfeld and Rogoff (1996). In spite of the theoretical appeal and some partial empirical support, actual current accounts do not seem to move as much as the standard theory predicts (as pointed out by Sheffrin and Woo, 1990; Otto, 1992; Ghosh, 1995; Obstfeld and Rogoff, 1996; and Hussein and de Melo, 1999, among others). The Feldstein and Horioka puzzle (1980) that a country's saving and investment are highly correlated is another manifestation of sticky current accounts. Tesar (1991), Backus and Smith (1993), Backus, Kehoe and Kydland (1992, 1994), and Glick and Rogoff (1995) show, from different angles, that the actual current account in the data is less variable than in the textbook model.

By introducing two tradable goods and assuming complete specialization, Cole and Obstfeld (1991) provide a theoretical connection between intra-temporal trade and intertemporal trade. In particular, the terms of trade response alone can provide perfect insurance against output shocks such that gains from international portfolio diversification are small. Here the elasticity of intertemporal substitution 
and the elasticity of substitution between home and foreign goods are key. With a unitary value for both elasticities of substitution, all adjustment is intra-temporal, irrespective of whether the shock is temporal or permanent. In further work by Corsetti, Dedola and Leduc (2008) and Corsetti, Dedola and Viani (2012), the current account response depends on the values of elasticities and persistence of shocks. For example, assuming a log utility function, if the intra-temporal elasticity of substitution is less than one, a temporary positive shock to net output worsens the terms of trade and induces the economy to run a current account deficit; if the intra-temporal elasticity of substitution is greater than one, the opposite happens. On the other hand, a near permanent shock to productivity, a news shock, or a growth shock would all keep the current account in deficit even when the intra-temporal trade elasticity is sufficiently large. In this literature, current account dynamics are driven by demand side effects and depend on a combination of the size of the elasticities and the persistence of shocks. In contrast, current account dynamics in our model are driven by supply side effects, and depend on differences of factor intensities and the mobility of labor across sectors but not qualitatively on trade elasticity.

We preview some of our key results here. First, with a flexible factor market, many shocks that normally would require a current account response in the standard intertemporal model could be accommodated by a change in the composition of output and intra-temporal trade with no need for a current account adjustment. The intuition behind this apparently major departure from the standard intertemporal approach can be understood by appealing to the Heckscher-Ohlin (HO) theory of goods trade. Consider a shock that would have produced a desire to import capital in the classic intertemporal model. Instead of adjusting the current account and importing capital directly, a country can adjust the total amount of investment by altering the composition of the two sectors, for example, importing capital indirectly via importing more of the capital-intensive product and at the same time exporting 
more of the labor-intensive product. In other words, the capital flow that would have taken place is substituted by a change in the composition of goods trade. It is important to note that this result depends neither on the values of the elasticities nor on the persistence of shocks. Second, in general, if an economy's factor markets are partially flexible, its response to a shock is a combination of a change in the current account (i.e., the intertemporal trade channel) and a change in the composition of output and goods trade (i.e., the intra-temporal trade channel). Intuitively, if factors are not completely mobile across sectors, then domestic output composition cannot change fully in response to a shock. So some of the adjustment must go through the current account channel. The relative importance of the current account channel depends on the degree of domestic labor market rigidity. Using a dynamic general equilibrium model, we show that as the domestic labor market becomes more rigid, the size of current account adjustment relative to the classic trade volume will become larger and the speed of adjustment towards the steady state equilibrium will be lower. Third, we present a series of empirical evidence on the connections between the degree of labor market rigidity and current account adjustment patterns that is consistent with our theory.

Our approach differs from the international real business cycle (IRBC) literature that also addresses the phenomenon of sticky current accounts. Obstfeld (1986), Mendoza (1991), and Baxter and Crucini (1993) show that a strong positive correlation between savings and investment can result from a persistent productivity shock in a dynamic general equilibrium model with no HO features. In such a model, a large transitory shock typically leads to a large current account response (i.e., no sticky current account). In comparison, our explanation is more general in the sense that a sticky current account is compatible with most shocks, including a large one-time (transitory) productivity shock. Our approach also generates different (and testable) predictions from other papers that have considered labor market frictions and trade barriers. Backus, Kehoe, and Kydland (1992) show that trade frictions lower the 
variability of net exports. Raffo (2008) argues that a class of preferences that embeds home production helps to explain countercyclical net exports. Fernandez de Cordoba and Kehoe (2000) incorporate frictions in the domestic labor market that impede resource reallocation between the non-tradable and tradable sectors. In their model, the greater the labor market frictions, the smaller the current account change. In contrast, in our model, an increase in labor market frictions could augment rather than dampen the current account change.

Some papers in the literature feature tradable and non-tradable sectors. The current account adjustment mechanism in our paper differs from that literature. In particular, a generalized Stolper-Samuelson mechanism is at work in our model, verified by us in a fully dynamic setting with an endogenous savings decision. This mechanism is responsible for some of our key results, but is not available in existing models with tradable and non-tradable sectors that do not emphasize cross-sector differences in factor intensity. We highlight our idea in a setting without a non-tradable sector, but adding a non-tradable sector will not fundamentally alter our results.

Cunat and Maffezzoli (2004) introduce a Heckscher-Ohlin structure into a DSGE model, but do not explore interactions between goods trade and capital flows and do not look into the role of labor market frictions in current account adjustments. The relationship between goods trade and capital flows is also examined by several recent papers. Antras and Caballero (2009) study the effect of credit constraints on international trade and capital flows and show that in less financially developed economies, trade and capital mobility are complements. Ju and Wei (2010 and 2011) study the quality of the financial system as a source of comparative advantage and as a motivation for two-way capital flows. ${ }^{1}$ Jin (2012) discusses the effect of a

\footnotetext{
${ }^{1}$ In Antras and Caballero (2009), financial underdevelopment is defined by the limited supply of entrepreneurial capital, which is a necessary input in one sector but not in the other sector. In their model, a less financially developed country exports the unconstrained good but imports the constrained good. As trade liberalization makes the less financially developed country produce more unconstrained goods and use more unconstrained capital, it leads to an inflow of unconstrained
} 
change in industrial composition on the direction of capital flows, and argues that when the composition effect dominates, capital tends to flow towards countries that become more specialized in capital-intensive industries. ${ }^{2}$ Costinot, Lorenzoni and Werning (2011) study how a country can use the saving tax to manipulate its terms of trade. These papers do not study how frictions in the domestic labor market can fundamentally alter the way the current account responds to shocks.

This paper is also related to the literature on dynamic Heckscher-Ohlin models pioneered by Oniki and Uzawa (1965), Bardhan (1965), Stiglitz (1970), and Deardorff and Hanson (1978). Other contributions in recent years include Chen (1992), Baxter (1992), Nishimura and Shimomura (2002), Bond, Trask and Wang (2003), Bajona and Kehoe (2006), and Caliendo (2011). Ventura (1997) studies trade and growth with a model of one final good, two intermediate goods, and labor-augmenting technology. As this literature typically focuses on the question of income convergence across countries, current account adjustment is not usually studied (and a balanced trade is often assumed).

The theory presented in this paper is related to an empirical literature in open-economy macroeconomics that estimates the speed of adjustment of the current account towards the long-run equilibrium (Milesi-Ferretti and Razin, 1998; Freund, 2000; Freund and Warnock, 2005; and Clarida, Goretti, and Taylor, 2005). This line of research typically finds that the current account has a tendency to regress back to its long-run equilibrium, with a speed of adjustment that is heterogenous across countries. The reason behind the cross-country heterogeneity in the adjustment speed is usually unexplained in existing studies. Our theory provides a micro-foundation

capital. Ju and Wei $(2010,2011)$ show that while FDI flows from financially developed countries to less financially developed countries, financial capital flows in the opposite direction. In this paper, we do not distinguish between constrained entrepreneurial capital and unconstrained capital, or between FDI and financial capital. Our focus in this paper is the current account balance, or the net borrowing (lending) of a country. In other words, we focus on the net capital flow, rather than the composition of gross capital flows.

${ }^{2}$ Our paper differs from Jin (2012) in both the setup and the research question asked. While she employs an OLG model, we use an infinite-horizon setup. While we focus on how factor market frictions affect the substitutability between goods trade and capital flows, she does not discuss factor market frictions. 
to understand these patterns.

Note that our theory does not imply that the standard intertemporal approach to current account is wrong. Indeed, Corsetti and Konstanious (2012) show that a key prediction of the standard model - that consumption is mostly driven by permanent shocks, and current account responds to temporary shocks - can account for the current account dynamics of the United States. This empirical pattern is also consistent with the prediction of our model when the labor market is at least somewhat rigid. However, our theory makes additional (and testable) predictions: If the labor market were to become more flexible, our model implies that one would have seen a smaller current account adjustment for a given temporary shock, and that more of the adjustment would take place via structural adjustments in the composition of sectors and in the aggregate investment. On the other hand, if the labor market is to be more rigid, our model predicts an opposite pattern: an even greater amount of current account adjustments are expected to be seen for a given temporary shock, but less structural change (changes in the composition of sectors) may take place. We will take these predictions to the data by exploring cross-country heterogeneity in labor market rigidities.

The empirical part of the paper provides three types of results. First, we report evidence that an economy's frequency in the adjustment of the goods trade composition is linked to its labor market rigidity. This is a necessary but not sufficient condition for our story. Second, we examine a time-series implication of our theory: the speed of current account adjustment (to its long run equilibrium) is lower in countries with a more rigid labor market. Third, we report evidence that a country's current account relative to the total trade volume is more variable if its labor market is more rigid. We interpret it as suggesting that economies with a more rigid labor market are more likely to use their current account to respond to shocks than economies with a more flexible labor market.

We organize the rest of the paper in the following way. Section 2 presents 
the basic model and proves our main theoretical result. Sector 3 calibrates the model with attention to how a country's external adjustment pattern varies with the degree of domestic labor market flexibility. Section 4 presents some empirical work examining the relationship between domestic labor market institutions and patterns of current account adjustment. Finally, Section 5 concludes and points to directions for future research.

\section{Basic Model}

We modify a standard small open economy dynamic stochastic general equilibrium model in two dimensions. First, we introduce two tradable sectors with different capital/labor intensities. Second, we assume that labor not only cannot move across countries, but also may not be costlessly and instantaneously reallocated between sectors within a country.

\subsection{Household}

The economy is inhabited by a continuum of identical and infinitely lived households that can be aggregated into a representative household. The representative household's intertemporal utility function is

$$
U=E_{t} \sum_{s=t}^{\infty} \theta_{s} U\left(C_{s}\right)
$$

where $C_{s}$ is the household's consumption of a final good at date $s$, and $\theta_{s}$ is the discount factor between period 0 and $s$. The discount factor is not a constant, and

evolves over time by following $\theta_{s+1}=\beta\left(\tilde{C}_{s}\right) \theta_{s}$, where $\theta_{0}=1$ and $\frac{d \beta\left(\tilde{C}_{s}\right)}{d \tilde{C}_{s}}<0$. We assume that the endogenous discount factor does not depend on the household's own consumption, but rather on the average per capita consumption $\tilde{C}_{s}$, which any individual household takes as given. This type of discount factor was originally proposed by Uzawa (1968), and introduced into the open economy macro literature 
by Obstfeld (1982) and Mendoza (1991). We will choose a specific functional form of $\beta\left(\tilde{C}_{t}\right)$ in calibrations.

The representative household owns both factors of production, capital $K$ and labor $L$, and sells its labor service in a competitive spot market. To simplify the analysis, we consider a fixed labor supply $L=\bar{L}$ in the text. (In an Appendix, we show that all our results remain qualitatively the same when the labor supply is endogenous.) The household supplies labor to both intermediate goods sectors. To model labor market frictions, we assume that the representative household has to pay a quadratic labor adjustment cost whenever it wishes to reallocate labor that deviates from the steady state allocation. That is, if the household supplies $L_{i t}$ to sector $i$ in period $t$, it bears the adjustment cost in the amount of $\frac{\lambda}{2}\left(L_{i t}-\bar{L}_{i}\right)^{2}{ }^{3}$ where $\lambda$ is a parameter representing the degree of labor market frictions in the economy, and $\bar{L}_{i}$ is the steady state level of labor in sector $i$. As a result, the wages in the two sectors do not have to be the same all the time.

The household holds foreign assets (a bond) in the amount of $B_{t+1}$ denominated in units of the final composite good. Trade in foreign assets is subject to a small portfolio adjustment cost in the form of $\frac{\psi_{b}}{2}\left(B_{t+1}-\bar{B}\right)^{2}$ (also denominated in units of the final composite good), where $\bar{B}$ is an exogenous steady state level of net foreign asset. ${ }^{4}$ The portfolio adjustment cost reflects not only narrowly defined transaction costs such as bid-ask spreads and capital controls, but also costs associated with information asymmetry across national borders. In addition, it can be understood as a shorthand for (not explicitly modeled) risks associated with cross-country differences in the legal systems, culture, and currencies. ${ }^{5}$

\footnotetext{
${ }^{3}$ The quadratic labor adjustment cost is extensively used in the literature. For example, see Hamermesh (1989), Cooper and Willis (2003), and Gali and Rens (2010). In these papers, the cost structure is on net changes in employment. The labor adjustment cost in Gali (2010) is simply interpreted as hiring cost. In our model, the cost is on the changes of sectoral employment from its steady state level; the labor adjustment cost catches the labor sector-specificity. In the short run, due to the mismatch between skills and sectors, there will always be resource loss during the process of labor adjustments.

${ }^{4}$ As in Schmitt-Grohé and Uribe (2003), Devereux, Lane and Xu (2006) and Uribe and Yue (2006), the portfolio adjustment cost eliminates the unit root in the economy's net foreign assets.

${ }^{5}$ Note that the portfolio adjustment cost is introduced to address a technical issue. In particular,
} 
The budget constraint and the capital accumulation equation faced by the representative household are given by

$$
\begin{gathered}
C_{t}+I_{t}+\sum_{i=1}^{2} \frac{\lambda}{2}\left(L_{i t}-\bar{L}_{i}\right)^{2}+\frac{\psi_{b}}{2}\left(B_{t+1}-\bar{B}\right)^{2}+B_{t+1}=\sum_{i=1}^{2} w_{i t} L_{i t}+r_{t} K_{t}+\left(1+r^{*}\right) B_{t} \\
K_{t+1}=K_{t}+I_{t} \\
L=L_{1 t}+L_{2 t}
\end{gathered}
$$

where $I_{t}$ is the investment in period $t$, and $w_{i t}$ and $r_{t}$ are the wage rate in sector $i$ and the domestic interest rate, respectively, while $r^{*}$ is the world interest rate. For simplicity, we assume no capital depreciation and no cost of adjusting capital between the two sectors. ${ }^{6}$

The first order conditions with respect to $C_{t}, K_{t+1}, B_{t+1}$, and $L_{i t}$ give intertemporal and intra-temporal optimization conditions

$$
\begin{aligned}
U_{c}^{\prime}\left(C_{t}\right) & =\beta\left(\tilde{C}_{t}\right) E_{t}\left[U_{c}^{\prime}\left(C_{t+1}\right)\left(1+r_{t+1}\right)\right] \\
U_{c}^{\prime}\left(C_{t}\right)\left[1+\psi_{b}\left(B_{t+1}-\bar{B}\right)\right] & =\beta\left(\tilde{C}_{t}\right) E_{t}\left[U_{c}^{\prime}\left(C_{t+1}\right)\left(1+r^{*}\right)\right] \\
w_{i t}-\lambda\left(L_{i t}-\bar{L}_{i}\right) & =\frac{\eta_{L t}}{\eta_{t}}, i=1,2
\end{aligned}
$$

where $\eta_{t}$ and $\eta_{L t}$ are Lagrange multipliers for the budget constraint and the labor supply constraint, respectively. Using equations (4) and (7), we have:

as pointed out by Mundell (1957), in the absence of any frictions, when capital flows are allowed in the standard Heckscher-Ohlin model, capital flows and goods trade are perfect substitutes. This implies that the Heckscher-Olin structure with capital flows has inherently multiple equilibria. A convex cost of adjusting the international asset position allows us to pin down a unique equilibrium. Note that when labor adjustment is costly, we can already pin down an equilibrium even with no bond adjustment costs. Since we are interested in comparing different current account responses as we vary the degree of labor market rigidity, we choose to hold the coefficient of the bond adjustment costs constant in these exercises. As will be explained later, the coefficient value of the bond adjustment costs in simulations will be guided by the existing literature.

${ }^{6}$ We analyze the effect of capital adjustment cost in the Appendix and show that it has similar effects on the economy as the labor adjustment cost. 


$$
2 \lambda\left(L_{1 t}-\bar{L}_{1}\right)=w_{1 t}-w_{2 t}, 2 \lambda\left(L_{2 t}-\bar{L}_{2}\right)=w_{2 t}-w_{1 t}
$$

\subsection{Production}

The production setting assumed in this paper is close in spirit to that in Ventura (1997). The main difference is in the treatment of current account. While international capital flows (or intertemporal trade) are prohibited by assumption in his model, we not only allow for intertemporal trade but make it a central focus of the discussion.

The production function for the final good is $Y_{t}=G\left(D_{1 t}, D_{2 t}\right)$, where $D_{i t}$ is the usage of intermediate good $i$ by the final good producer. The production function for intermediate good $i(=1,2)$ is $X_{i t}=f_{i}\left(A_{t} L_{i t}, K_{i t}\right)$ where $A_{t}$ measures labor productivity, which is exogenous and identical in both sectors. $A_{t} L_{i t}$ can be understood as effective labor. All production functions are assumed to be homogeneous of degree one. ${ }^{7}$ The final good is taken as the numeraire and its price is normalized to 1 . The market is perfectly competitive.

The unit cost function for $X_{i t}$ is $\phi_{i}\left(\frac{w_{i t}}{A_{t}}, r_{t}\right)$. Free entry ensures zero profit for the intermediate goods producers. Let $p_{i}$ be the price of intermediate goods $i$. We assume that the country's endowment is always within the diversification cone so that both intermediate goods are produced. In period $t$ the zero profit condition implies that

$$
p_{1 t}=\phi_{1}\left(\frac{w_{1 t}}{A_{t}}, r_{t}\right) \text { and } p_{2 t}=\phi_{2}\left(\frac{w_{2 t}}{A_{t}}, r_{t}\right)
$$

The profit maximization by the final good producer requires that

$$
p_{1 t}=\frac{\partial G\left(D_{1 t}, D_{2 t}\right)}{\partial D_{1 t}} \text { and } p_{2 t}=\frac{\partial G\left(D_{1 t}, D_{2 t}\right)}{\partial D_{2 t}}
$$

Since $G($.$) is homogenous of degree one, the zero profit for the final good producer$

\footnotetext{
${ }^{7}$ It has been recognized that labor augmenting type of technical changes in the steady state is consistent with the empirically observed lack of a trend in the K/Y raito. See Uzawa (1961) and Jones and Scrimgeour (2008).
} 
implies that

$$
G\left(D_{1 t}, D_{2 t}\right)=p_{1 t} D_{1 t}+p_{2 t} D_{2 t}
$$

\subsection{Equilibrium}

In equilibrium, free trade in intermediate goods leads to equal prices across countries in every period. That is, $p_{i t}=p_{i}^{*}, i=1,2$, where $p_{i}^{*}$ is taken as exogenously given. Following the assumptions in the standard Hecksher-Ohlin model, we assume that production functions in all countries are the same. Assuming that the rest of the world is in a steady state so that wage rates are equal across two sectors, we have:

$$
p_{1}^{*}=\phi_{1}\left(\frac{w^{*}}{A^{*}}, r^{*}\right) \text { and } p_{2}^{*}=\phi_{2}\left(\frac{w^{*}}{A^{*}}, r^{*}\right)
$$

In equilibrium, we have the following market clearing conditions in the home country

$$
\begin{aligned}
K_{t} & =K_{1 t}+K_{2 t} \\
L_{t} & =L_{1 t}+L_{2 t} \\
G\left(D_{1 t}, D_{2 t}\right) & =C_{t}+I_{t}+\sum_{i=1}^{i=2} \frac{\lambda}{2}\left(L_{i t}-\bar{L}_{i}\right)^{2}+\frac{\psi_{b}}{2}\left(B_{t+1}-\bar{B}\right)^{2}
\end{aligned}
$$

Equation (15) implies that the output of the final good covers not only consumption

and investment, but also the labor adjustment cost and bond adjustment cost. The current account balance over period $t$ is defined as $C A_{t}=B_{t+1}-B_{t}$; thus, using the zero profit condition for both intermediate goods and final goods (equations (9) and equation (11)) and the final good market clearing condition (equation (15)), we can rewrite the budget constraint as

$$
C A_{t}=p_{1 t}\left(X_{1 t}-D_{1 t}\right)+p_{2 t}\left(X_{2 t}-D_{2 t}\right)+r^{*} B_{t}
$$

The first two terms on the right hand side describe the economy's net trade surplus. The last term on the right hand side is the factor payment (interest 
income) on the net foreign asset position. In other words, the equilibrium conditions imply that the country's net addition to its foreign asset holdings is equal to trade surplus plus the interest income on the net foreign asset position (which of course is consistent with the definition of current account).

We are now ready to discuss the substitutability between intertemporal trade and intra-temporal trade. When the labor market is frictionless but the bond adjustment is costly $\left(\lambda=0, \psi_{b}>0\right)$, we wish to demonstrate that shocks to the economy are absorbed through changes in the composition of outputs and intra-temporal trade without any adjustment in current account. When the labor adjustment is costly but the bond market is frictionless $\left(\lambda>0, \psi_{b}=0\right)$, we will show that the opposite is true. That is stated as the following proposition. ${ }^{8}$

Proposition 1 Suppose that the representative agent has perfect foresight. If labor is freely mobile across sectors but the bond adjustment is costly, shocks to the economy are absorbed completely through a change in the composition of outputs and intra-temporal trade without any adjustment in the current account. If the bond adjustment cost is zero but labor adjustment is costly, on the other hand, shocks to the economy are absorbed completely through intertemporal trade without any adjustment in the composition of outputs.

Proof. When $\lambda=0$ and $\psi_{b}>0$, equations (8) imply that $w_{1 t}=w_{2 t}=w_{t}$. Two zero profit conditions in (9) uniquely determine domestic factor prices, $\frac{w_{t}}{A_{t}}$ and $r_{t}$. As $p_{i t}=p_{i}^{*}$, using equations (9) and (12), we must have $\frac{w_{t}}{A_{t}}=\frac{w^{*}}{A^{*}}$ and $r_{t}=r^{*}$ so that factor prices in the two countries are equalized. Note that this holds for any value of $A_{t}$ and the discount factor. Using equations (5) and (6), we then obtain that $B_{t+1}=\bar{B}$. In other words, if there is a shock to either productivity or discount factor, there will be no change in the amount of bond holding (i.e., no change in the current account), and all adjustments are carried out by a change in the composition

\footnotetext{
${ }^{8}$ We assume that the consumer has perfect foresight to prove Proposition 1, but maintain the DSGE setup in the calibrations.
} 
of outputs.

When $\psi_{b}=0$ and with perfect foresight, equations (5) and (6) imply that $U_{c}^{\prime}\left(C_{t+1}\right)\left(r_{t+1}-r^{*}\right)=0$. That is true only if $r_{t+1}=r^{*}$. Using equations (9) and (12), therefore, we must have $\frac{w_{1 t}}{A_{t}}=\frac{w^{*}}{A^{*}}=\frac{w_{2 t}}{A_{t}}$. Since $\lambda>0$ and $w_{1 t}=w_{2 t}$, the two equations in (8) imply that $L_{i t}=\bar{L}_{i}$, which also imply that $K_{i t}=\bar{K}_{i}$. They have to hold for any value of $A_{t}$ and the discount factor. Thus, if there is a shock to either productivity or discount factor, there will be no change in the sectoral composition of outputs. The response to the shock has to take the form of a change in the current account (i.e., a change in bond holdings).

A few remarks are in order here. First, this proposition is very general. In particular, it places no restrictions on the utility and production functions other than the standard ones. Second, it shows the substitutability between intertemporal trade and intra-temporal trade as alternative means to respond to a shock in the two extreme cases of either no frictions in the labor market or no frictions in buying and selling international assets. Third, while we are not able to obtain analytical results for all combinations of frictions, it is reasonable to conjecture that the response of an economy to a shock generally involves a combination of some intertemporal trade and intra-temporal trade. We will use calibrations below to explore the adjustment mechanisms under different combinations of frictions.

\section{Calibration Analysis}

We adopt the following standard functional forms for preference and technology. The utility function takes the form of $U\left(C_{t}\right)=\frac{C_{t}{ }^{1-\gamma}}{1-\gamma}$, where $\gamma$ is the inverse of the elasticity of inter-temporal substitution. The production function for the final good is $G\left(D_{1 t}, D_{2 t}\right)=\frac{1}{\omega^{\omega}(1-\omega)^{1-\omega}} D_{1 t}^{\omega} D_{2 t}^{1-\omega}$, where $D_{1}$ and $D_{2}$ are intermediate goods 1 and 2, respectively, and $\omega$ and $1-\omega$ are the shares of intermediate good 1 and 2 in the final good production. The production function for intermediate 
$\operatorname{good} i$ is $f_{i}\left(A_{i t} L i t, K_{i t}\right)=\frac{1}{\alpha_{i}^{\alpha_{i}}\left(1-\alpha_{i}\right)^{1-\alpha_{i}}} K_{i t}^{\alpha_{i}}\left(A_{i t} L_{i t}\right)^{1-\alpha_{i}}$, where $a_{i}$ is the capital share in producing intermediate good $i$. We let $\alpha_{1}<\alpha_{2}$ so that sector 1 is labor intensive. The endogenous time discount factor takes the following form:

$\beta\left(\tilde{C}_{t}\right)=\beta\left(\frac{\tilde{C}_{t}}{\bar{C}}\right)^{-\psi} \exp \left(v_{t}\right)$, where $\psi>0$ and $v_{t}$ is a preference shock. This form is a variant of the discount factor in Choi, Mark and Sul (2008).

The model is calibrated in a standard way (following Backus, Kehoe, and Kydland (1992, 1994, 1995), and Kehoe and Peri (2002)). The parameter values are reported in Table 1. We set the inverse of the elasticity of intertemporal substitution $\gamma=2$, the steady state discount factor $\beta=0.99$, which implies that the annual world interest rate will be $4 \%$. We assume equal shares of the two intermediate goods in the final good production, so $\omega=0.5$. We set $\alpha_{1}=0.30$ and $\alpha_{2}=0.42$ so that the economy-wide capital share $\left(\alpha_{1}+\alpha_{2}\right) / 2=0.36$. Sector 1 is labor intensive and sector 2 is capital intensive. We will show later that the difference in factor intensities across sectors is crucial in driving our results. Following Schmitt-Grohé and Uribe (2003), the bond adjustment cost coefficient is set to be 0.0007. The value of the parameter that measures the labor marker friction, $\lambda$, will take on several values to represent different degrees of labor market rigidities: $\lambda=0,4$ and 20. The different values of $\lambda$ also reflect different elasticities of labor supply at the sectoral level. The value of $\psi$ in the endogenous time discount factor does not affect the steady state but affects the dynamics of the model. We set $\psi=0.1$, which is close to the value chosen by Choi, Mark and Sul (2008).

\subsection{Benchmark Results}

In this section, we report the impulse responses of the key macro variables to both temporary and persistent shocks to productivity $A_{t}$ and time preference $\beta_{t}$, respectively. While we focus on the dynamics of the current account, foreign asset position and the level of international trade in each intermediate good, we also report the response of aggregate consumption, capital and labor (both at the aggregate and 
Table 1: Parameter Values for the Small Open Economy

\begin{tabular}{ccc}
\hline Symbol & Definition & Value \\
\hline$\beta$ & discount factor in steady state & 0.99 \\
$\gamma$ & coefficient of risk aversion & 2 \\
$\alpha_{1}$ & capital share in intermediate good sector 1 & 0.3 \\
$\alpha_{2}$ & capital share in intermediate good sector 2 & 0.42 \\
$\omega$ & share of intermediate goods 1 in final good & 0.5 \\
$\psi_{b}$ & coefficient of bond adjustment cost & 0.0007 \\
$\lambda$ & the parameter of labor market friction & $0 / 4 / 20$ \\
$\psi$ & the parameter of endogenous discount factor & 0.1 \\
\hline
\end{tabular}

sectoral levels). We assume that the economy in period 0 is in the steady state with zero foreign asset $B=0$ and the net trade in each intermediate sector is zero, that is, $N X_{i}=X_{i}-D_{i}=0$. A shock hits the economy in period 1. In the following figures, the dynamics of $C A_{t}, N X_{i t}$, and $B_{t}$ are reported in terms of their ratios to the steady state GDP, while the other variables are expressed in terms of percentage changes from the steady state.

\subsubsection{Temporary and Persistent Productivity Shocks}

We start with a temporary positive productivity shock. In particular, the log of $A$ increases by 1 percent in period 1 , and goes back to the steady state value of $A=1$ in period 2 and remains at that value in all subsequent periods. (In this case, in the standard intertemporal model, there will be a temporary one-period increase in the current account, to be followed by a series of diminishing current account deficits. While the one-time productivity increase has temporarily bumped the output upward, the sum of consumption and investment does not go up by the same proportion at the same time. This generates a current account surplus in the first period following the shock.)

The current account response of our economy is very different from the standard model if the labor market is completely flexible. Figures 1 and 2 report the responses 
of the economy under a completely flexible labor market $(\lambda=0)$ and a somewhat rigid labor market $(\lambda=4)$, respectively. The horizontal axis represents time, while the vertical axis represents deviations of the variables from the corresponding steady state values.

With a flexible labor market $(\lambda=0)$, the aggregate consumption (in row 1 column 1 of Figure 1) jumps up in period 1 and then gradually declines to the steady state level (which is similar to the standard model without HO features). As capital starts to respond to the shock in period 2, the capital to effective labor ratio, $K / A L$, drops in period 1 and then gradually increases to steady state level (in row 1, column 2 of Figure 1). The adjustments of the outputs, capital and labor in the two sectors are presented in the next six graphs (the last two columns of row 1 and the four columns in row 2). They essentially follow the standard Heckscher-Ohlin theory, and are governed by the change in $K / A L$. The output $X_{1}$, capital usage $K_{1}$, labor usage $L_{1}$, and the net export $N X_{1}$ in the labor intensive sector all jump up in the first period and then gradually decline to the steady state level, while the patterns of production and factor usage in the capital intensive sector (sector 2) are essentially mirror images of the labor intensive sector. Importantly, Sector 1's exports go up in period 1, while Sector 2's imports go up in period 1 by the same amount (row 3, columns 1 and 2). The net trade for the economy as a whole remains at zero.

There is a stark difference between the current model and the standard intertemporal model. Instead of a current account surplus, we do not observe any adjustment of current account (row 3, column 3 of Figure 1). The response to the shock is entirely carried out through a change in the sectoral composition of intermediate goods production and trade. The values of savings, investment, current account, and capital stock in the first four quarters after a temporary productivity shock are reported in the top panel of Table 2. Because the cost of moving factors between the two sectors is low relative to the cost of adjusting the country's external asset 
position, it is optimal to avoid a current account adjustment (row 3, column 4 of Figure 1). The change in the composition of sectoral output bears the full burden of adjustment, and produces an increase in the aggregate investment. In a sense, with a flexible labor market, the current account is determined first, and the domestic investment moves next to match the change in the savings. Note that as the shock is temporary, output returns to the steady state level immediately, but consumption remains above the steady state level, which implies a dissaving after the first period. To avoid the higher cost of adjusting the international asset position, the investment also declines to match the change in savings.

With a relatively rigid labor market $(\lambda=4)$, the results are more similar to the standard model. The dynamics of the same set of variables in this case are presented in Figure 2. The values of savings, investment, current account, and capital stock in the first four periods following a temporary productivity shock are presented in the second panel of Table 2. The most important consequence of labor market rigidity is that the domestic factor reallocations and sectoral outputs cannot respond to the shock as quickly (rows 1 and 2 of Figure 2) as under a flexible labor market. Due to a now higher cost of adjusting the sectoral composition quickly, some of the burden of adjustment shifts to a change in the net foreign asset position. The gradual adjustment of the composition of the outputs and intermediate goods trade (row 3, columns 1 and 2 of Figure 2) implies that the aggregate investment cannot adjust as much as in the case of a flexible labor market, and the current account must run a surplus on impact (row 3, column 3, of Figure 2). In other words, both intertemporal trade and intra-temporal trade are utilized to respond to the shock. Of course, the net foreign asset position rises first and then gradually returns to the new steady state (row 3, column 4 of Figure 2).

We now consider a persistent productivity shock. Specifically, $\log A$ increases by 1 percent in period 1, and follows a law of motion of $\log \left(A_{t+1}\right)=0.9 \log \left(A_{t}\right)$ for $t \geq 1$. (In the standard model with no heterogeneity in factor intensity, this would have 
generated a current account deficit in the first period. Intuitively, in the standard model, the persistent productivity increase would lead to a big enough increase in investment such that the sum of the increases in consumption and investment exceeds that of the contemporaneous output.) In our setup, we see very different results, depending on the degree of labor market flexibility. If the labor market is flexible, there will be no current account response. If the labor market is partially inflexible, we will see a combination of a current account deficit and some change in the sectoral composition. Figures 3 and 4 trace out the impulse response of the key variables under a flexible labor market $(\lambda=0)$ and a rigid labor market $(\lambda=4)$, respectively. The values of savings, investment, and current account in the initial four periods following a persistent shock are presented in the lower two panels of Table 2. We find that the responses of the economy are qualitatively the same as those after a transitory shock in Figures 1 and 2, except that now the current account runs a deficit at the beginning if the labor market is rigid. In the case of a flexible labor market, while both consumption and investment go up in response to the positive productivity shock, the investment does not need to go up by as much with a proper corresponding adjustment of the sectoral composition.

To summarize, the current model with a rigid labor market generates qualitatively similar predictions as the standard model. In contrast, the current model with a flexible labor market produces dramatically different results from the standard model in that the current account no longer responds to productivity shocks.

\subsubsection{Temporary and Persistent Shocks to Time Preference}

Consider a one-period negative shock to the time preference. In particular, $\beta$ declines by 10 percent in period 1 , and goes back to the steady state value $\beta=0.99$ in period 2. A decrease in $\beta$ in period 1 means that the representative household has become less patient and would like to consume more in period 1. In the standard model, to finance more current consumption, the economy would borrow and run a current 
account deficit. In our model, both external and internal adjustments could be used to respond to the shock. Proposition 1 states that, if the labor market is completely flexible, a change in the sectoral composition of output and a corresponding change in the composition of intra-temporal trade would be sufficient to accommodate the shock with no need for a change in the current account. To see this numerically, Figure A1 depicts how various variables in the economy respond to this shock under a flexible labor market $(\lambda=0) \cdot{ }^{9}$ As expected, while consumption jumps in the first period, there is no movement in either the current account or the net foreign asset holdings.

All the actions take place through a realignment of sectoral output and sectoral exports and imports. To be more concrete, the temporal decrease in patience causes the representative household to reduce $\mathrm{K}$ in period 1, leading to a decline in $K / A L$ in period 1 which recovers gradually in subsequent periods toward the new steady state. In response to the trajectory of the economy-wide $K / A L$, capital and labor shift out of the capital intensive sector into the labor intensive sector. Correspondingly, both domestic output and the net export of the labor intensive sector jump in period 1 and return gradually to the new steady state (which is still higher than the old steady state). The domestic output of the capital intensive sector drops in period 1 and then converges gradually to the new steady state, while imports of the capital intensive intermediate good jump in period 1 and then converge gradually to the new steady state. It is important to note that, throughout the adjustment process, the absolute amounts of the change in net exports in the two intermediate goods exactly cancel each other out, so that there is no change in economy-wide net exports (and therefore no change in the country's net foreign asset holdings).

In the case of a relatively rigid labor market $(\lambda=4)$, our discussion in the previous section suggests that the economy's response may involve a combination of intertemporal and intra-temporal trade. Figure A2 presents adjustments in various

\footnotetext{
${ }^{9}$ To save space, we relegate all figures in the case of $\beta$ shocks to Appendices.
} 
key variables to this shock. As expected, while some of the adjustments take place through a change in the sectoral composition of output and intra-temporal trade, the economy nonetheless runs a current account deficit at the beginning (and pays back the debt gradually in future periods).

We now turn to a persistent shock to the time preference. In particular, we assume that $\beta$ falls from the steady state value of 0.99 by 10 percent in period 1 , but follows an $\operatorname{AR}(1)$ process of $\hat{\beta}_{t+1}=0.4 \hat{\beta}_{t}$ for all subsequent periods $t \geq 1$. Figure A3 traces out the dynamics of the key variables in response to this shock when the labor market is fully flexible. The patterns for all variables are qualitatively similar to those in Figure A1. Because the persistent shock represents a bigger shock on a cumulative basis, the magnitude of the sectoral adjustments in capital and labor reallocation and in output is also bigger than in the case of a temporary shock. The most important feature of Figure A3 that we would like to highlight is a conspicuous absence of any movement in either the current account or the foreign asset position.

Figure A4 traces out the response patterns of the key variables to the same persistent shock when the labor market is somewhat rigid $(\lambda=4)$. The patterns are now different from Figure A3 but qualitatively similar to those in Figure A2, except that the magnitude of the adjustments tends to be larger in response to a persistent shock. As expected, with labor market frictions, a combination of current account adjustment and sectoral output adjustment takes place.

\subsection{Varying Labor Market Frictions}

In the previous subsection, we chose two particular values of labor market frictions $(\lambda=0$ and 4$)$. Now, we wish to systematically vary the value of $\lambda$ from 0 to 20 and study how the response patterns of the economy vary accordingly. Obviously, if we were to replicate the previous set of graphs, we would have had too many of them. Instead, we report only the responses of three variables: (a) the total trade volume, (b), the importance of current account movement relative to the total trade 
volume, and (c) the speed of adjustment of the current account toward the steady state. By tracing out how each of them responds to a common shock as a function of $\lambda$, we aim to capture how the composition of intra-temporal and intertemporal trade depends on the extent of domestic labor market frictions.

We report the results under persistent productivity shocks in Figure 5. For each value of $\lambda$ from zero to 20 , we compute the average value of the total trade volume $\left|N X_{1}\right|+\left|N X_{2}\right|$ (the sum of exports and imports) over the first 8 quarters. The results are presented in the top graph in Column 1 of Figure 5. It is clear that as the labor market becomes less flexible, the total trade volume becomes progressively smaller.

We next compute the ratio of the average current account in absolute value over the first eight quarters to the average total trade volume over the same period. The results are presented in the top graph in Column 2 of Figure 5. When $\lambda=0$ (the case of a frictionless labor market), the current account is not used to respond to the productivity shock, and the ratio of the current account to the total trade volume is zero. As the labor market becomes less flexible, the proportion of the adjustment that has to go through the current account rises. In other words, the economy's response to the productivity shock would depend progressively more on the intertemporal trade channel and less on the intra-temporal trade channel. As a result, the ratio of the current account to the total trade volume rises.

Third, we wish to investigate the speed of current account adjustment toward the steady state as a function of $\lambda$. To do so, we set a threshold for distance from the steady state for $B_{t} / G D P$ as 0.01 . If the absolute value of $B_{t} / G D P$ is smaller than the threshold, we say that the foreign asset position has converged to the steady state level (or it is within "striking distance" from the steady state). If it takes longer for an economy to reach the threshold cold, we label its current account adjustment as slower. The results are presented in the bottom graph in column 1 of Figure 5. Generally speaking, the more rigid the labor market, the longer it takes 
for the economy to converge towards the steady state.

We next study how the response patterns to a persistent shock to the time preference vary by labor market frictions. The trajectories of the average total trade volume, the ratio of the current account to the total trade volume, and the required number of quarters it takes for the foreign asset position to be smaller than the threshold are presented in the three graphs in Figure A5. It is obvious that the three graphs are qualitatively the same as their counterparts in Figure 5.

We have also examined the response patterns to a temporary shock to productivity and to a temporary shock to time preference. Qualitatively, the exact same relationship between these three variables and $\lambda$ are observed. We do not report the graphs to save space.

\subsection{Sectoral Heterogeneity in Factor Intensities}

The key departure of our model from the classic intertemporal trade model is the presence of multiple tradable sectors with different factor intensities. Here we verify that when the capital labor ratio in the two sectors becomes more similar, our model will also behave more similar to the classic one-sector intertemporal trade model in which all adjustments to a shock take place exclusively through the current account.

We first consider a persistent shock to productivity $A$. We keep $\lambda=4$ and hold the aggregate capital share at $\left(\alpha_{1}+\alpha_{2}\right) / 2=0.36$. The last graph of Figure 5 traces out the ratio of the average current account in absolute value over the first eight quarters to the average total trade volumes over the same period on the vertical axis. The horizontal axis traces the difference in the capital shares in output between the two sectors (while holding the economy-wide capital/labor ratio constant). As expected, as the capital shares become more similar in the two sectors (moving from the right to the left on the horizontal axis), the importance of current account adjustment relative to the total trade volume also rises.

We next consider a persistent shock to time preference (while keeping $\lambda=4$ 
and holding the aggregate capital share at $\left.\left(\alpha_{1}+\alpha_{2}\right) / 2=0.36\right)$. The last graph of Figure A5 traces out the relationship between the ratio of current account to total trade volume and the difference in capital share between the capital-intensive and the labor-intensive sectors. Again, as the factor intensity becomes more similar in the two sectors (moving from the right to the left on the horizontal axis), the relative importance of current account adjustment also rises.

\section{Some Empirical Evidence}

Motivated by the theoretical analysis, we look at some cross-country evidence on the relationship between domestic labor market rigidity and current account dynamics.

An economy is potentially subject to many shocks at a given point in time, most of which are not measured and recorded systematically. One handicap we face is that we do not have systematic measures of all the shocks for each country. In the absence of an exhaustive catalogue of all the relevant shocks, we shall assume that the distribution of the shocks is similar across countries over a long enough time period (once we condition on a country's volatility of output and price level). Under this assumption, we investigate three questions. First, does the country-level volatility of goods trade depend on a country's labor market rigidity? Second, does the country-level volatility of current account relative to the volatility of total trade volume depend on a country's labor market rigidity? Third, does labor market rigidity slow down the convergence of an economy's current account to its long-run equilibrium?

Our theory implies that the answers to all three questions are yes. In particular, greater labor market rigidity tends to elevate the relative use of current account in an economy's adjustment process in response to a shock. If the distribution of shocks is similar across countries over a period of time, those economies with a relatively more rigid labor market should exhibit a lower volatility of total trade volume but 
a higher volatility of current account relative to total trade volume.

Our theory also implies that the speed of current account adjustment tends to be lower in economies with a relatively rigid labor market. In addition, while the existing empirical literature finds cross country differences in the speed of current account convergence, it does not provide an explanation, nor does it link them to observable country characteristics. Our theory can be thought of as a micro-foundation for heterogeneity in the convergence speed and predicts that domestic labor market flexibility is a source of the heterogeneity.

Note that the empirical work focuses on the links between domestic labor market flexibility and current account adjustment patterns. We deliberately do not report results involving domestic financial market development. While we could model frictions in the domestic capital market in an analogous way as those in the domestic labor market, their effects on current account adjustments are different. In particular, unlike labor market frictions, an increase in frictions in the domestic capital market tends to directly raise frictions in accumulating and decumulating foreign assets. Since the two frictions have an opposite effect on the current account response, this implies that the net effect of the current account response to a given increase in domestic capital market is ambiguous. More details on this point can be found in Appendix 6.2. (When we include proxies for domestic financial development or credit market constraints, the coefficients are often insignificant or unstable. For this reason, we choose not to report these results to keep the tables relatively clean.)

\subsection{Preliminary: Labor Market Rigidity and Trade Structure Flexibility}

Before we investigate the three questions, we first examine whether domestic labor market rigidity affects the churning of a country's trade structure (i.e., the average change in the composition of exports and imports over time). Our theory can work only if a more flexible labor market can translate into more flexible production and trade structures when a shock hits the economy. 
Absent a satisfactory way to compute the churning of capital/labor ratio in exports and imports, we compute the degree of churning for exports and imports country by country, using most disaggregated data available from the United Nations' Comtrade database at the HS 6 digit level.

To be precise, let $s_{X}(j, h, t)=$ the share of product $h$ in country $j$ 's exports in year $t$, and $s_{M}(j, h, t)=$ the share of product $h$ in country $j$ 's imports in year $t$. Then the Trade Structure Churning Index for country $j$, or Churning $(j)$ for short, is defined by

$\operatorname{Churning}(j)=\frac{1}{T} \sum_{t=1}^{T} \sum_{h}\left[\left|s_{X}(j, h, t)-s_{X}(j, h, t-2)\right|+\left|s_{M}(j, h, t)-s_{M}(j, h, t-2)\right|\right]$ where $\mathrm{t}=1996,1998,2000,2002$, and 2004, and $T=5$. The churning index is bounded between zero (no change in trade structure) and 2 (maximum possible change). The value of the trade structure churning index is reported in Column 3 of Table A1. Since agriculture, dairy farming, and fishery activities (agriculture for short) are generally difficult to switch in and out of, we have also computed a churning index excluding these activities and reported it in Column 4 of Table A1.

The index for labor market rigidities comes from the World Bank Investment Climate Assessment (ICA) based on an enterprise survey conducted by the World Bank in 2003. ${ }^{10}$ Specifically, it is the proportion of managers/survey respondents in a country who report labor regulation as a major business constraint (out of 18 categories listed on the questionnaire, including quality of infrastructure, macroeconomic instability, tax rate, tax administration, corruption, and crime. Each respondent can report multiple categories as major constraints.) This measure of labor market rigidity is preferable to simply coding the labor market regulations on the book, since the strength of enforcement varies widely across countries. A strong law that is not well enforced is not as binding for firms as a weaker regulation that is strictly

\footnotetext{
${ }^{10} \mathrm{http}$ ///iresearch.worldbank.org/InvestmentClimate. The data were used in the World Bank's World Development Report 2005.
} 
enforced. Since survey responses presumably take enforcement into account, the ICA index can be regarded as a de facto measure of labor market rigidity. The labor market rigidity index is presented in Column 5 of Table A1.

A scatter plot of the trade structure churning index (for all sectors) against the labor market rigidity index is reported in Figure 6. A negative association between the two is evident: countries with a more rigid labor market have a lower degree of churning of their trade structures. With a t-statistic of -1.75 , the slope coefficient is statistically different from zero at the $10 \%$ level. Brazil is an apparent outlier on the lower right part of the graph. If one removes Brazil, the new slope coefficient is still negative; but with a t-statistic of -1.60 , it is only different from zero at the $15 \%$ level. If we remove agriculture, dairy, and fishery activities from the computation

of the trade churning index, the new scatter plot is presented in Figure 7. The negative slope coefficient is more significant (at the $1 \%$ level with a t-statistic at -2.11) than in Figure 6. After removing Brazil, the slope coefficient is still negative and significant at the $10 \%$ level (with a t-statistic at -1.94). To summarize, the data suggest that domestic labor market rigidity is negatively associated with the speed of turnover of an economy's trade structure.

This result is after all not surprising: one would think that impediments to labor reallocation should necessarily slow down the adjustment in the trade structure. Figures 6 and 7 can also be read as a confirmation that the measure of labor market rigidity captures useful information about the actual operation of the labor markets in these economies.

\subsection{Labor Market Rigidity and Current Account Adjustment Speed}

We now turn to evidence on the speed of current account adjustment. Based on the third graph in both Figures 5 and 5A, our theory predicts that, after either a shock to productivity or a shock to time preference, it takes longer for an economy's foreign asset holdings to reach within a threshold from the steady state equilibrium 
if the domestic labor market is more rigid. If the underlying distribution of shocks is similar across countries, we interpret the prediction as implying that the speed of convergence of the current account increases with the flexibility of domestic labor market.

Before we present our empirical results, we first make a note of the existing empirical literature in open-economy macroeconomics that estimates the speed of convergence of the current account towards long-run equilibrium (Freund and Warnock, 2005; and Clarida, Goretti, and Taylor, 2005). Many studies find heterogeneous speeds of convergence across countries but provide no theoretical foundation. Our theory can be regarded as a possible microfoundation for such estimations - the heterogeneity in labor market institutions is a source of heterogeneity in the current account adjustment patterns.

Our own empirical work follows a two-step procedure. In step one, for every country in the sample, we estimate the speed of convergence of the current account-to-GDP ratio towards the steady state. This estimation applies the standard specification in the literature and utilizes the time series information country by country. In step two, we relate the speed of convergence to a country's degree of labor market rigidity. This step is done for a cross section of countries. We explain the two steps in turn. (Note that we could, in principle, combine the two steps, which might improve the efficiency of the estimation but at a cost of introducing possible biases due to potential heterogeneity in the steady state current accounts across countries. Since we do not have a power problem, we choose to sacrifice some efficiency in order to minimize possible biases.)

\subsubsection{Estimating the Speed of Convergence for Current Account}

Let $x(j, t)$ be country $j$ 's ratio of current account to GDP in time $t$, or, $x(j, t)=$ $c a(j, t) / g d p(j, t)$. Using $\Delta$ to denote the first difference of a variable, we estimate 


$$
\Delta x(j, t)=\alpha(j)+\beta(j) x(j, t-1)+e(j, t)
$$

for the period 1980-2005. Under the null hypothesis that the current account as a share of GDP does not converge, $\beta(j)=0$. Under the alternative hypothesis that the ratio of current account to GDP converges to a long-run steady state, $\beta(j)$ is negative (and smaller than one in absolute value). The greater is $\beta(j)$ in absolute value, the faster is the speed of convergence. Note that this specification does not impose the constraint that the long-run value of the current account-to-GDP ratio should be zero. The country-specific long-run value in this specification is given by $-\alpha(j) / \beta(j)$. The idea that different countries may have different long-run values is consistent with Kraay and Ventura (2000).

Our theory focuses on the case of a small open economy. A large country's current account could behave systematically differently since foreign labor market flexibility can also affect it. In the empirical tests, we exclude large economies, defined as those whose GDP accounts for more than 5\% of world GDP in 2005. Consequently, the United States, Japan and Germany are excluded from the sample.

The estimation is done at both quarterly and annual frequencies. Data on current account and GDP come from the IMF's International Financial Statistics database. Potential serial correlation in the error term is mopped up by higher orders of the lags of the dependent variable (we will later consider a non-linear specification that allows for faster convergence when the current account is sufficiently far away from its long-run equilibrium level). We now turn to the second step of our empirical design, namely, relating the estimated speed of current account convergence to labor market rigidity. 


\subsubsection{Relating the Adjustment Speed of Current Account to Labor Market Rigidity}

Let $R(j)$ be an index of country $j$ 's rigidity of labor market. We relate a country's speed of current account adjustment to its labor market rigidity as follows:

$$
\beta(j)=c+\gamma R(j)+u(j)
$$

Under the null hypothesis that current account adjustment is not related to labor market rigidity, $\gamma=0$. Under the alternative hypothesis that a more rigid labor market leads to a slower adjustment in current account, $\gamma>0$ (recall that $\beta(j) \mathrm{s}$ are non-positive).

We now turn to the basic results from estimating Equation (18). As a first step, we estimate the speed of current account convergence country by country using quarterly data on the ratio of current account-to-GDP. There are 30 countries for which we simultaneously have quarterly current account data and a measure of labor market rigidity. These regression results are not reported to save space. As a second step, we implement the simplest possible bi-variate linear regression exploring any linkage between a country's speed of current account convergence and its labor market rigidity. The result is reported in Column 2 of Table 3. The slope coefficient is 1.06 and statistically significant. This is consistent with the notion that the current account convergence is systematically slower in countries with a more rigid labor market.

The convergence speed for the current account could be affected by factors other than labor market rigidity. Unfortunately, the literature does not provide much guidance on this, and most empirical estimation on current account convergence uses only univariate time series. Since a key benefit of a flexible exchange rate regime is supposed to provide a country with better insulation from external shocks, one might think that exchange rate regime matters for the speed of adjustment. It is 
well recognized that a country's self-declared (de jure) exchange rate regime does not often describe its actual behavior well. We therefore add a de facto exchange rate regime classification a la Reinhart and Rogoff (2004). Specifically, a country in a given time period is classified into one of six regimes: a peg to a foreign currency, a crawling peg, a managed float, a float, free falling, and dual exchange rates. Since our regression is a cross-section, we assign an exchange rate regime classification to a country if it spends a majority of the time in that regime during the sample period. The regression result is reported in Column 3 of Table 3. It turns out that the exchange rate regime designations are not statistically significant. This result is consistent with Chinn and Wei (2013). Of more importance to us, the coefficient on labor market rigidity is basically unchanged (with a point estimate of 1.17 and still being statistically significant).

In addition, one might think that the level of economic development (or the quality of public institutions) can affect the speed of adjustment. So we also include per capita GDP (in logarithm) as a control variable. The result is reported in Column 4. It turns out that the level of development does not play a significant role in the current account adjustment either.

We have tried other variations: merging various flexible exchange rate regimes into one, using an alternative measure of de facto exchange rate classification a la Levy-Yeyati and Sturzenegger (2003). These results are reported in the last four columns of Table 3. In all these cases, the coefficient on labor market rigidity remains positive and statistically significant at the $10 \%$ level. This suggests that the pattern that a more rigid labor market is associated with a slower current account adjustment is robust.

The results so far use quarterly data. However, because annual data on current account/GDP ratio have fewer missing observations than quarterly data, we can work with a larger set of countries. Table 4 reports a set of regressions that relate the current account adjustment parameters estimated using annual data with labor 
market rigidity. The same pattern emerges: a more rigid labor market is associated with a systematically slower speed of current account adjustment. Now, however, the coefficient on per capita GDP is significant as well: the current account adjusts faster in poorer countries on average. The coefficients on the exchange rate regime classifiers are still insignificant, though the negative sign on various flexible regime dummies is consistent with the notion that current account adjusts faster in countries with a flexible exchange rate regime. To check if this result is driven by any outlier, Figure 8 plots the estimates of $\beta(j)$ (speed of current account convergence) against $R(j)$ (labor market rigidity). The figure suggests a robustly positive relationship that is unlikely to be driven by one or two outliers.

\subsubsection{Non-linear TAR Model}

As Freund and Warnock (2005) and Clarida, Goretti, and Taylor (2005) suggest, the speed of current account adjustment is likely to be non-linear, with faster adjustment for larger initial deviations from the long-run equilibrium. To take this into account, we now estimate the speed of current account adjustment by a threshold autoregressive (or TAR) model.

The TAR model allows the CA/GDP ratio to follow a unit-root process (i.e., no convergence) if its value stays within a certain range but reverts to its long-run equilibrium when the $\mathrm{CA} / \mathrm{GDP}$ ratio exceeds some threshold values. To be more specific, the CA/GDP ratio in the TAR model is assumed to come from the following data generating process,

$$
\begin{array}{rlr}
\Delta x(j, t) & =\alpha_{1}(j)+\beta(j) x(j, t-1)+e(j, t) \text { if }|x(j, t-1)|>\phi(j) \\
& =\alpha_{2}(j)+e(j, t) & \text { otherwise }
\end{array}
$$

where $\alpha_{1}(j), \alpha_{2}(j), \beta(j)$, and $\phi(j)$ are parameters to be estimated (for every country $j$ in the sample). In practice, the estimation is done in sequence. The value of $\phi(j)$ 
is determined by a grid search. If transaction costs or other factors create a zone of non-converging current account, the TAR model provides a more powerful way to detect global stationarity than the linear AR specification - even if the true behavior of CA/GDP does not conform to the TAR specification.

Estimation of these models can be done via maximum likelihood or sequential conditional least squares. Procedurally, we estimate the pooled model using the fixed effects panel estimator by performing a grid search over possible values of $\phi$. Starting with an initial value of $\phi$ at 0.003 , the search adds 0.003 in each successive round until $\phi$ reaches the 75 th fractile of the distribution of $x(j, t-1)$.

After we obtain estimates of $\beta(j)$ from a TAR model country by country, we again connect them with the countries' level of labor market rigidity. The results are presented in Tables A2 and A3 (when the convergence speeds for CA/GDP are estimated with quarterly and annual data, respectively). The coefficients on the measure of labor market rigidity are positive in all specifications and statistically significant at the $10 \%$ level in 13 out of 14 cases. This again confirms the notion that more labor market rigidity is associated with slower convergence for CA/GDP to its long-run equilibrium. In Table A3, there is some evidence that the convergence is faster for countries with a flexible exchange rate regime, or a lower level of income.

\subsection{Volatility of Current Account-to-Total Trade Ratio}

Our theory (the first and the second graphs in Figure 5) predicts that an economy relies less on gross trade and more on current account to respond to shocks if its domestic labor market is more rigid. Under the assumption that the distribution of the underlying shocks is the same across countries, we should observe a negative relationship between the volatility of the gross trade volume and labor market rigidity, and a positive relationship between the volatility of the current account relative to the gross trade volume and labor market rigidity.

In this subsection, we compute these volatility measures, country by country, 
using the time series over the period 1980-2005. We then regress them on the measure of labor market rigidity, plus control variables. To be precise, let $\operatorname{std}(j)_{1}=$ standard deviation of total trade for country $j, \operatorname{std}(j)_{2}=$ standard deviation of $\mathrm{CA} /$ total trade for country $j, R(j)$ be its labor market rigidity, and $Z(j)$ be a vector of other controls, then the specifications are:

$$
\begin{aligned}
& \operatorname{std}(j)_{1}=c_{1}+\gamma_{1} R(j)+Z(j) \eta_{1}+\varepsilon_{1}(j) \\
& \operatorname{std}(j)_{2}=c_{2}+\gamma_{2} R(j)+Z(j) \eta_{2}+\varepsilon_{2}(j)
\end{aligned}
$$

The proposition that a country with a more rigid labor market tends to rely more on its current account (relative to total trade) to adjust to shocks is interpreted as implying $\gamma_{1}<0$ and $\gamma_{2}>0$. Since both real and nominal shocks could affect CA and total trade directly, we include the standard deviation of log CPI and standard deviation of $\log$ GDP (scaled by the mean of $\log$ GDP) as control variables. In addition, we allow exchange rate regimes to have a direct effect on the variabilities of total trade and the $\mathrm{CA} /$ total trade ratio.

The regression results for the standard deviations of total trade and CA/total trade are presented in the first four columns of Tables 5 and 6 , respectively. The estimates for $\gamma_{1}$ and $\gamma_{2}$ are consistently negative and positive, respectively, and statistically significant at the 10 percent level. The estimates are consistent with the interpretation that labor market rigidity affects a country's relative reliance on its current account for adjustments to shocks.

A scatter plot of $\operatorname{std}(j)_{1}$ against $R(j)$ suggests that Brazil, Guyana, and Malaysia may be outliers (not reported to save space). We exclude these three countries and re-do the regressions. The results are presented in the last four columns of Table 5. The negative and statistically significant association between the variability of total trade and labor market rigidity remains. For $\operatorname{std}(j)_{2}$, a scatter plot suggests that 
Brazil and Nicaragua may be outliers (not reported). We exclude these two countries and re-do the regressions. The results are presented in the last four columns of Table 6 . With this modification, the positive and statistically significant association between the variability of the $\mathrm{CA} /$ total trade ratio and labor market rigidity appears to be robust to excluding possible outliers.

Taking together the various pieces of evidence, the data suggest that a country's current account adjustment and trade structure adjustment are closely linked to its labor market flexibility in a way that is consistent with the model in this paper.

\section{Conclusion}

This paper proposes a new theory of current account adjustment that incorporates a Heckscher-Ohlin structure into a dynamic general equilibrium model. The integration of trade and macroeconomic theories generates new insight on the connection between intertemporal and intra-temporal trades. In particular, in our framework, an economy's response to a shock generally involves a combination of a change in the composition of output and a change in the current account, with the relative importance of the two channels determined by the degree of domestic labor market flexbility. In the extreme case when labor is completely flexible, any shock can be accommodated by a change in the composition of output (and goods trade) with no change in the current account. A relatively more rigid labor market slows down the speed of convergence by the current account to its steady state equilibrium.

Three pieces of empirical evidence are presented. First, a rigid labor market makes an economy less nimble and more likely to experience a low churning of its trade structure. Second, a higher rigidity of the labor market reduces the speed of convergence of the current account. Third, a country with a rigid labor market is likely to exhibit a lower variance of total trade, but higher variance of the current account relative to total trade. These patterns are consistent with the theory's 
predictions.

With our new framework, many topics in standard open-economy macroeconomics, such as the role of fiscal policy, non-tradable sector, and asymmetric information, could be re-visited. It will be interesting to rethink these topics systematically and to re-examine the data if appropriate. We leave these for future research.

\section{References}

[1] Antras, Pol and Ricardo J. Caballero (2009), "Trade and Capital Flows: A Financial Frictions Perspective," Journal of Political Economy, 117(4), 701-744.

[2] Backus, David K., Patrick J. Kehoe, and Finn E. Kydland (1992), "International Real Business Cycles," Journal of Political Economy 100: $745-775$.

[3] Backus, David K., Patrick J. Kehoe, and Finn E. Kydland (1994), "Dynamics of the Trade Balance and the Terms of Trade: The J-Curve," American Economic Review 84:1, 84-103

[4] Backus, David K. and Gregor W. Smith (1993), "Consumption and Real Exchange Rates in Dynamic Economies with Non-Traded Goods," Journal of International Economics, 35, 297-316.

[5] Bajona, Claustre and Timothy J. Kehoe (2006), "Demographics in Dynamic Heckscher-Ohlin Models: Overlapping Generations versus Infinitely Lived Consumers," NBER Working Paper 12566.

[6] Bardhan, P. K. (1965), "Equilibrium Growth in the International Economy," Quarterly Journal of Economics 79: 455-464.

[7] Baxter, Marianne (1992), "Fiscal Policy, Specialization, and Trade in the Two-Sector Model: The Return of Ricardo?" Journal of Political Economy 100: $713-744$.

[8] Baxter, Marianne and Mario J. Crucini (1993), "Explaining Saving-Investment Correlations," American Economic Review 83:3, 416-436

[9] Bond, Eric W., Kathleen Trask and Ping Wang (2003), "Factor Accumulation and Trade: Dynamic Comparative Advantage with Endogenous Physical and Human Capital," International Economic Review 44: 1041-1060.

[10] Caliendo, Lorenzo (2011), "On the Dynamics of the Heckscher-Ohlin Theory," Working Paper, Princeton University.

[11] Chen, Zhiqi (1992), "Long-Run Equilibria in a Dynamic Heckscher-Ohlin Model," Canadian Journal of Economics 25: 923-943.

[12] Chinn, Menzie, and Shang-Jin Wei (2013), "A Faith-based Initiative Meets the Evidence: Does a Flexible Exchange Rate Regime Really Facilitate 
Current Account Adjustments?" Review of Economics and Statistics, 95 (1): $168-184$.

[13] Choi, Horag, Nelson C. Mark, and Donggyu Sul (2008), "Endogenous Discounting, the World Saving Glut and the U.S. Current Account", Journal of International Economics, 75: 30-53.

[14] Clarida, Richard, Manuela Goretti, and Mark P. Taylor (2005), "Are There Thresholds of Current Account Adjustment in the G7?" In G7 Current Account Imbalances: Sustainability and Adjustment, edited by Richard Clarida, The University of Chicago Press, Chapter 5.

[15] Cole, Harold L. and Maurice Obstfeld (1991), "Commodity Trade and International Risk Sharing," Journal of Monetary Economics, 28, 3-24.

[16] Corsetti, Giancarlo, Luca Dedola, and Sylvain Leduc (2008), "International Risk Sharing and the Transmission of Productivity Shocks," Review of Economic Studies, 75, 443-473.

[17] Corsetti, Giancarlo, Luca Dedola, and Francesca Viani (2012), "The International Risk Sharing Puzzle is at Business Cycle and Lower Frequency," Canadian Journal of Economics, 45(2): 448-471.

[18] Corsetti, Giancarlo and Panagiotis Konstantinou (2012), "What Drives US Foreign Borrowing? Evidence on External Adjustment to Transitory and Permanent Shocks," American Economic Review, 102(2): 1062-92.

[19] Cooper, Russell and Jonathan Willis (2009), "The Cost of Labor Adjustment: Inferences from the Gap," Review of Economic Dynamics, 12(4): 632-647.

[20] Costinot, Arnaud, Guido Lorenzoni and Ivan Werning (2011), "Intertemporal Trade Policy," Working Paper.

[21] Cunat, Alejandro and Marco Maffezzoli (2004), "Heckscher-Ohlin Business Cycles," Review of Economic Dynamics, 555-585.

[22] Cunat, Alejandro and Marc Melitz (2012), "Volatility, Labor Market Flexibility and Comparative Advantage" Journal of the European Economic Association, 10:225-254.

[23] Devereux, Michael, Philip Lane, and Juanyi Xu (2006), "Exchange Rates and Monetary Policy in Emerging Market Economies", Economic Journal, vol. 116, 478-506.

[24] Feldstein, Martin and Charles Horioka (1980), "Domestic Savings and International Capital Flows," Economic Journal, June 1980, 90, 314-329.

[25] Fernandez de Cordoba, G. and Timothy J. Kehoe (2000), "Capital Flows and Real Exchange Rate Fluctuations Following Spain's Entry into the European Community," Journal of International Economics, 51 (2000), 49-78.

[26] Freund, Caroline and Francis Warnock (2005), "Current Account Deficits in Industrial Countries: The Bigger They Are, the Harder They Fall?" In 
G7 Current Account Imbalances: Sustainability and Adjustment, edited by Richard Clarida, The University of Chicago Press.

[27] Gali, Jordi and Thijs van Rens (2010), "The Vanishing Procyclicality of Labor Productivity," Working Paper.

[28] Ghosh, Atish R. (1995), "International Capital Mobility amongst the Major Industrialised Countries: Too Little or Too Much?" The Economic Journal, 105(428): 107-128.

[29] Glick, Reuven and Kenneth Rogoff (1995), "Global versus Country-Specific Productivity Shocks and the Current Account," Journal of Monetary Economics, 35, 159-192.

[30] Hamermesh, Daniel S. (1989), "Labor Demand and the Structure of Adjustment Costs," Americal Economic Review, 79(4): 674-689.

[31] Hussein, Khaled A. and de Mello, Luiz Jr. (1999), "International Capital Mobility in Developing Countries: Theory and Evidence," Journal of International Money and Finance 18: 367-381.

[32] Jin, Keyu, (2012), "Industrial Structure and Financial Capital Flows," American Economic Review, 102(5): 2111-2146.

[33] Jones, C.I., and D. Scrimgeour, 2008, "A New Proof of Uzawa's Steady State Growth Theorem," Review of Economics and Statitics 90: 180-182.

[34] Ju, Jiandong and Shang-Jin Wei (2007), "Current Account Adjustment: Some New Theory and Evidence," NBER Working Paper 13388.

[35] Ju, Jiandong and Shang-Jin Wei (2010), "Domestic Institutions and the Bypass Effect of International Capital Flow," American Economic Journal: Economic Policy, November, pp. 173-204.

[36] Ju, Jiandong and Shang-Jin Wei (2011), "When Is Quality of Financial System a Source of Comparative Advantage?" Journal of International Economics, 84, 178-187.

[37] Kraay, Aart, and Jaume Ventura (2000), "Current Accounts in Debtor and Creditor Countries," Quarterly Journal of Economics, November, pp 1137-66.

[38] Levy-Yeyati, Eduardo, and Federico Sturzenegger (2003), "To Float or to Fix: Evidence on the Impact of Exchange Rate Regimes on Growth," American Economic Review, Vol. 93 (4), pp. 1173-1193, 2003.

[39] Mendoza, Enrigue (1991), "Real Business Cycles in a Small Open Economy," American Economic Review 81, 797-818.

[40] Nishimura, K. and K. Shimomura (2002), "Trade and Indeterminacy in a Dynamic General Equilibrium Model," Journal of Economic Theory 105: 244-260.

[41] Obstfeld, Maurice (1982), "Aggregate Spending and the Terms of Trade: Is There a Laursen-Metzler Effect?" Quarterly Journal of Economics 97, 251-270. 
[42] Obstfeld, Maurice (1986), "Capital Mobility in the World Economy: Theories and Measurement," Carnegie-Rochester Conference Series on Public Policy, Spring, 24, 55-103.

[43] Obstfeld, Maurice, and Kenneth Rogoff (1996), Foundations of International Macroeconomics, Cambridge, MA: MIT Press.

[44] Oniki, H. and H. Uzawa (1965), "Patterns of Trade and Investment in a Dynamics Model of International Trade," Review of Economic Studies 32: $15-38$.

[45] Otto, Glenn (1992), "Testing a Present-Value Model of the Current Account: Evidence from US and Canadian Time Series," Journal of International Money and Finance 11(5): 414-430.

[46] Raffo, Andrea (2008), "Net Exports, Consumption Volatility and International Business Cycle Models," Journal of International Economics, 75: 14-29.

[47] Reinhart, Carmen and Kenneth Rogoff (2004), "A Re-interpretation of Exchange Rate Regimes", Quarterly Journal of Economics. 119(1): 1-48

[48] Sachs, Jeffrey (1981), "The Current Account and Macroeconomic Adjustment in the 1970s," Brookings Papers on Economic Activity 1: 201-268.

[49] Sachs, Jeffrey (1982), "The Current Account in the Macroeconomic Adjustment Process," Scandinavian Journal of Economics 84: 147-159.

[50] Sheffrin, Steven M and Wing Thye Woo (1990), "Present Value Tests of an Intertemporal Model of the Current Account," Journal of International Economics, 29(3-4): 237-253.

[51] Svensson, Lars E. O. and Assaf Razin (1983), "The Terms of Trade and the Current Account: the Harberger-Laursen-Metzler Effect," Journal of Political Economy 91: 97-125.

[52] Tesar, Linda L. (1991), "Saving, Investment, and International Capital Flows," Journal of International Economics, 31: 55-78.

[53] Ventura, Jaume (1997), "Growth and Interdependence," Quarterly Journal of Economics 112: 57-84.

[54] Uribe, Martin and Vivian Z. Yue, (2006), "Country Spreads and Emerging Countries: Who Drives Whom?" Journal of International Economics, 69: $6-36$.

[55] Uzawa, H., 1961, "Neutral Inventions and the Stability of Growth Equilibrium," Review of Economic Studies 28: 117-124 


\section{Appendix (for online publication)}

\subsection{Endogenous Labor Supply}

The representative households' preferences over consumption and leisure flows are summarized by the following utility function

$$
U=E_{t} \sum_{s=t}^{\infty} \theta_{s} U\left(C_{s}, 1-L_{s}\right)
$$

where $\theta_{s+1}=\beta\left(\tilde{C}_{s}\right) \theta_{s}$ and $\frac{d \beta\left(\tilde{C}_{s}\right)}{d \tilde{C}_{s}}<0 ; C_{s}$ is the per-capital consumption at date $s ; L$ is the time share devoted to labor at date t. Households own both factors of production, capital $K$ and labor $L$, and sell their service in the competitive spot market.

The budget constraint and capital accumulation equation faced by the households are give by

$$
\begin{aligned}
C_{t}+I_{t}+\sum_{i=1}^{2} \frac{\lambda}{2}\left(L_{i t}-\bar{L}_{i}\right)^{2}+\frac{\psi_{b}}{2}\left(B_{t+1}-\bar{B}\right)^{2} & +B_{t+1}=\sum_{i=1}^{2} w_{i t} L_{i t}+r_{t} K_{t}+\left(1+r^{*}\right) B_{t} \\
K_{t+1} & =K_{t}+I_{t} \\
L_{1 t}+L_{2 t} & =L_{t}
\end{aligned}
$$

Using the same functional forms in the text, we then derive the first order conditions with respect to $C_{t}, K_{t+1}, B_{t+1}, L_{t}$ and $L_{i t}$ and conduct calibrations. All results are qualitatively similar to the case of fixed labor supply, and are available upon request to the authors.

\subsection{Capital Adjustment Costs}

We now add capital adjustment costs. Suppose the households supply $K_{i t}$ to sector $i$ in period $t$. We assume that they will bear the adjustment cost $\frac{\lambda_{K}}{2}\left(K_{i t}-\bar{K}_{i}\right)^{2}$, where $\lambda_{K}$ is a parameter that measures capital market frictions in sector $i$. The budget constraint and capital accumulation equation now become:

$$
\begin{gathered}
C_{t}+I_{t}+\sum_{i=1}^{2} \frac{\lambda}{2}\left(L_{i t}-\bar{L}_{i}\right)^{2}+\sum_{i=1}^{2} \frac{\lambda_{K}}{2}\left(K_{i t}-\bar{K}_{i}\right)^{2}+\frac{\psi_{b}}{2}\left(B_{t+1}-\bar{B}\right)^{2}+B_{t+1} \\
=\sum_{i=1}^{2} w_{i t} L_{i t}+\sum_{i=1}^{2} r_{i t} K_{i t}+\left(1+r^{*}\right) B_{t} \\
K_{i t+1}=K_{i t}+I_{i t}, \text { for } i=1,2 \\
L_{1 t}+L_{2 t}=L
\end{gathered}
$$

Similar to the analysis in the text, we derive the first order conditions with both 
labor and capital adjustment costs and then conduct calibrations. For simplicity, we assume that the labor adjustment cost is zero in the calibration. All results of capital adjustment costs are qualitatively similar to that of labor adjustment costs. In particular, as the capital adjustment cost becomes larger, there will be more current account adjustments relative to the change in trade volume. Note that the cost of domestic capital adjustments $\lambda_{K}$ and the cost of capital $\psi_{b}$ may be correlated. When the level of financial development in a country is lower, one would expect both $\lambda_{K}$ and $\psi_{b}$ to be larger. More formally, let us assume that $\psi_{b}=\psi_{b}\left(\lambda_{K}\right)$ and $\frac{d \psi_{b}}{d \lambda_{K}}>0$. In this case, the effect on current account adjustment patterns of an increase in domestic financial development is ambiguous: on the one hand, a larger $\lambda_{K}$ induces more current account adjustments; on the other hand, as a larger $\lambda_{K}$ also leads to a larger $\psi_{b}\left(\lambda_{K}\right)$, this can reduce current account adjustments. This means that increasing domestic financial development is different from improving domestic labor market flexibility as far as current account adjustments are concerned. 
Figure 1: Impulse response to a temporary A shock without labor market friction
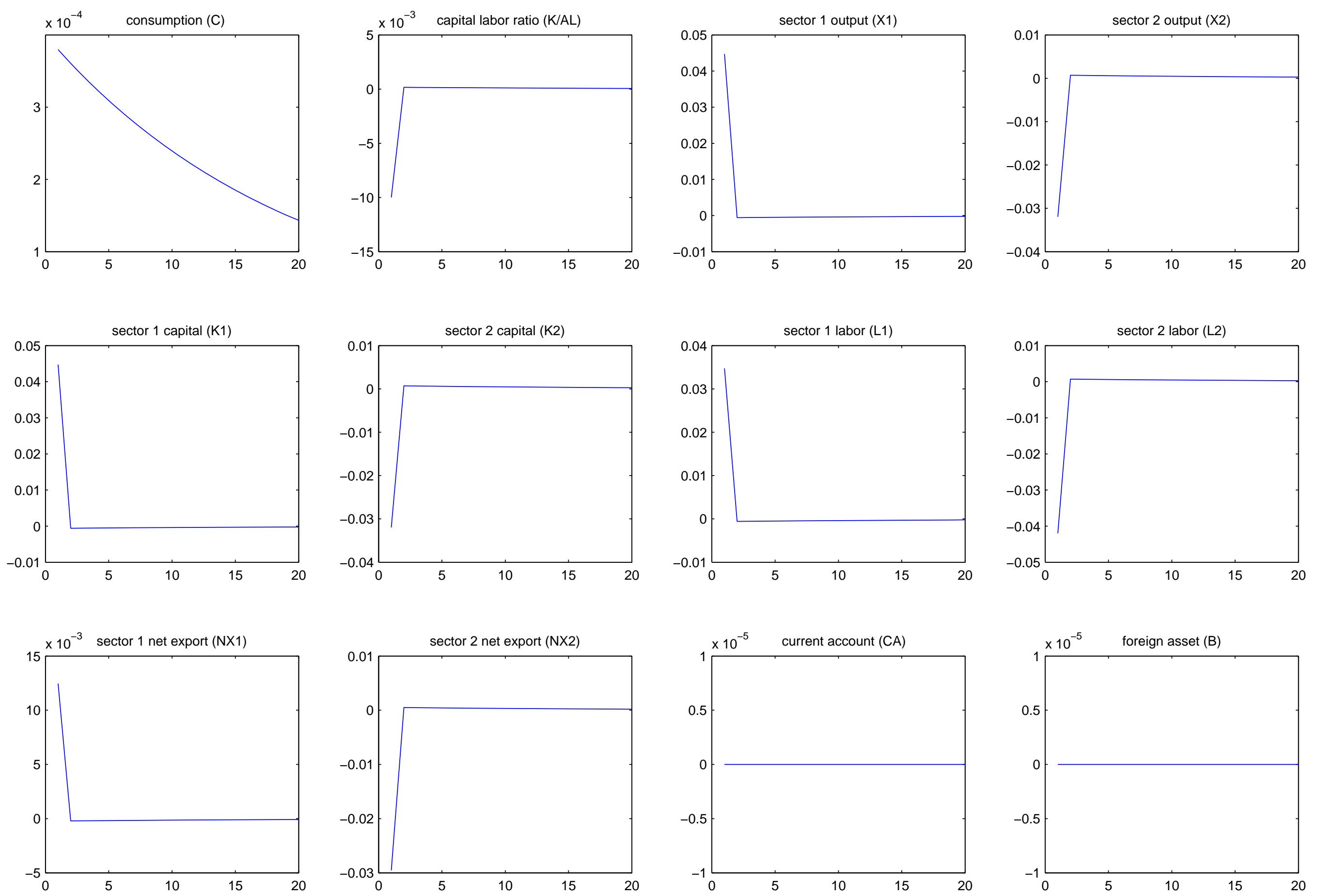
Figure 2: Impulse response to a temporary A shock with labor market friction
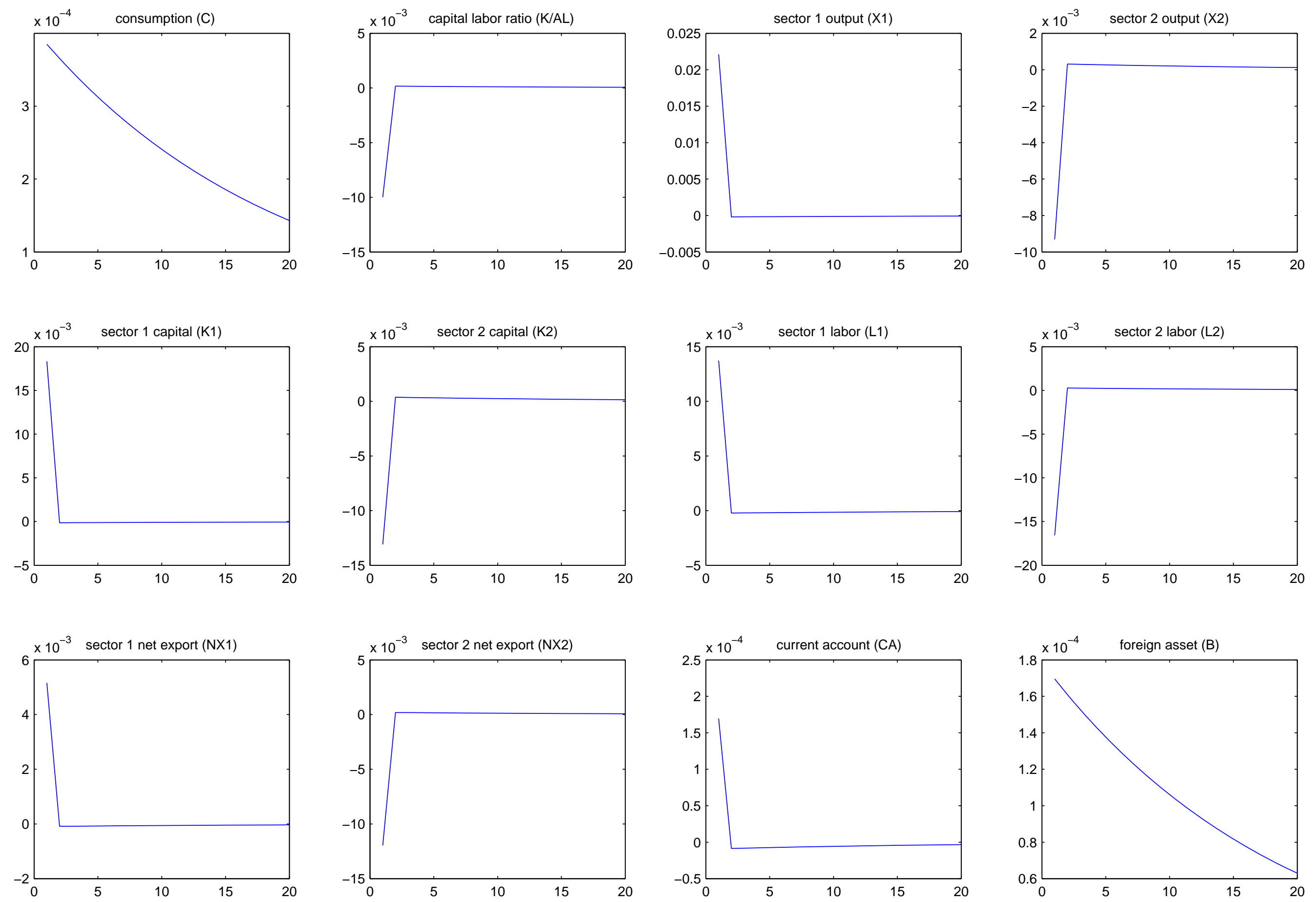
Figure 3: Impulse response to a persistent A shock without labor market friction
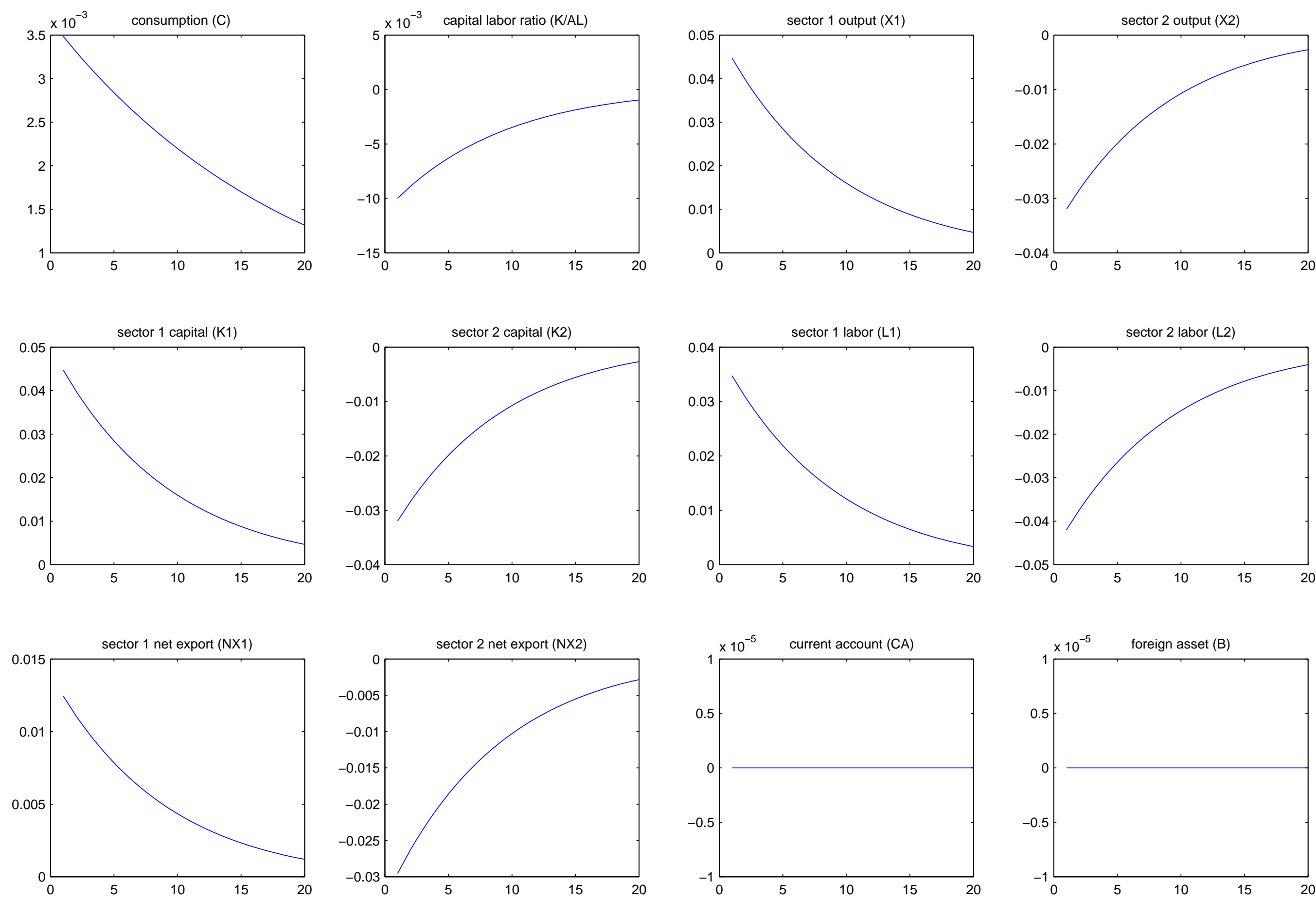
Figure 4: Impulse response to a persistent A shock with labor market friction
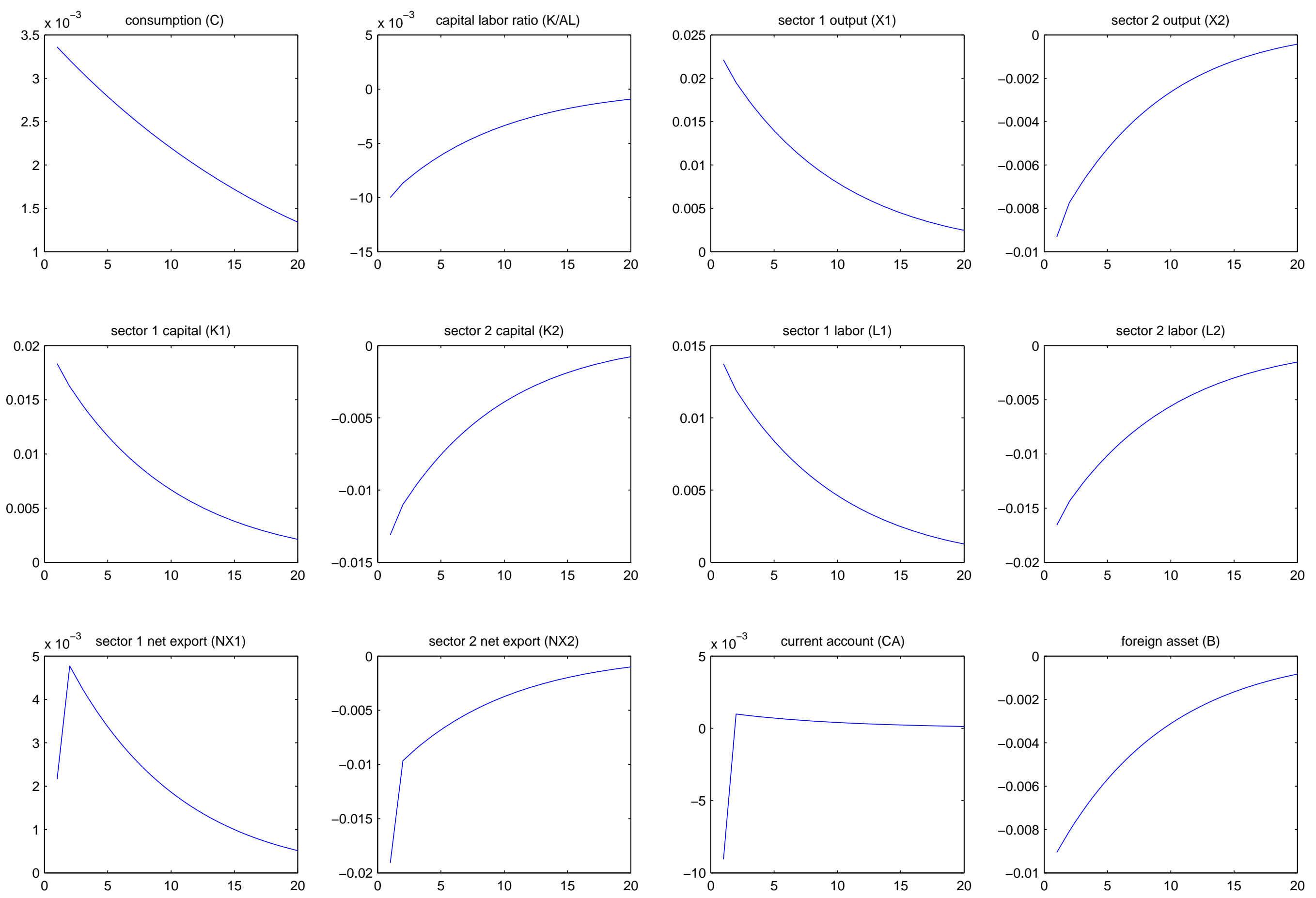
Figure 5: The Case of a Productivity Shock
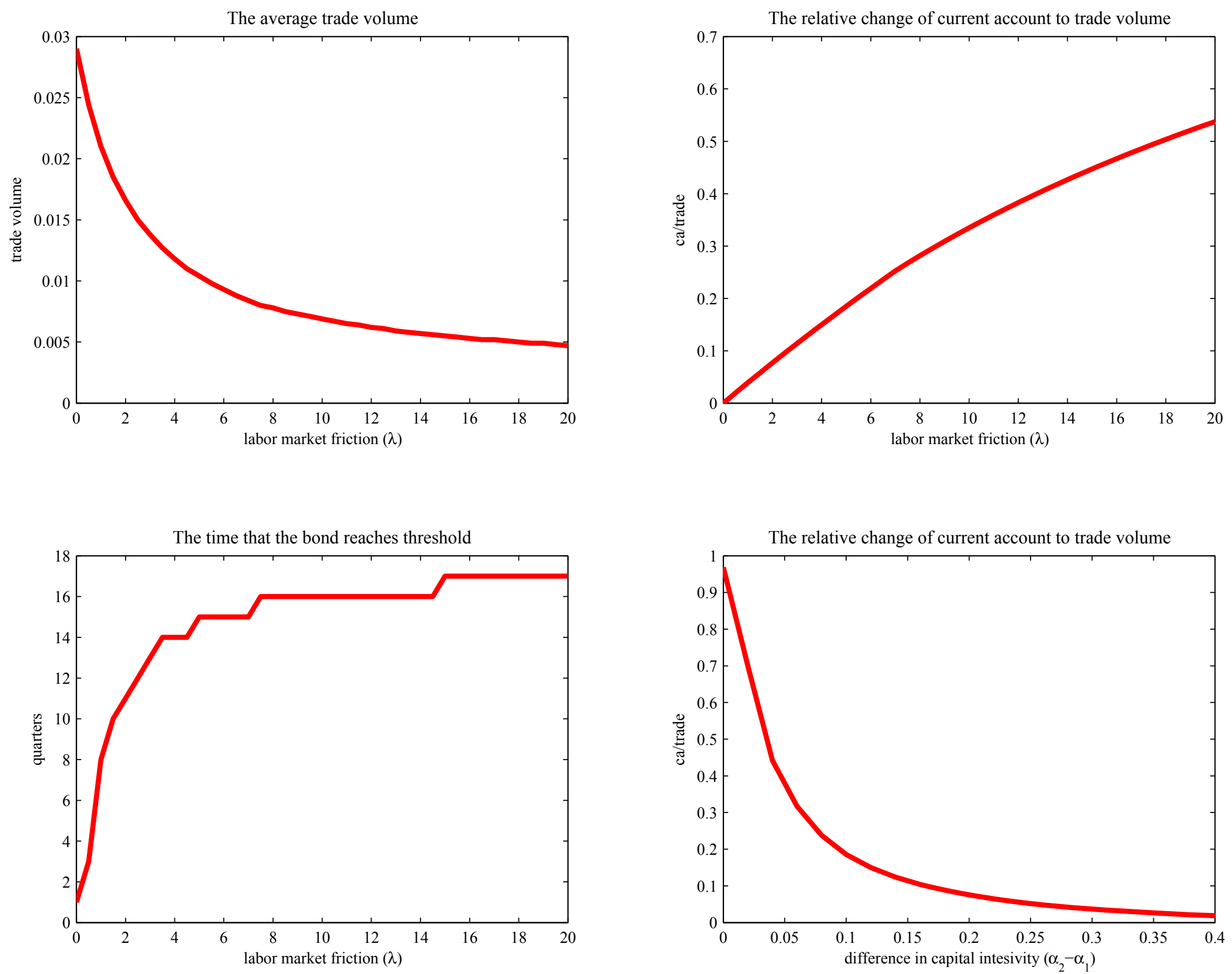


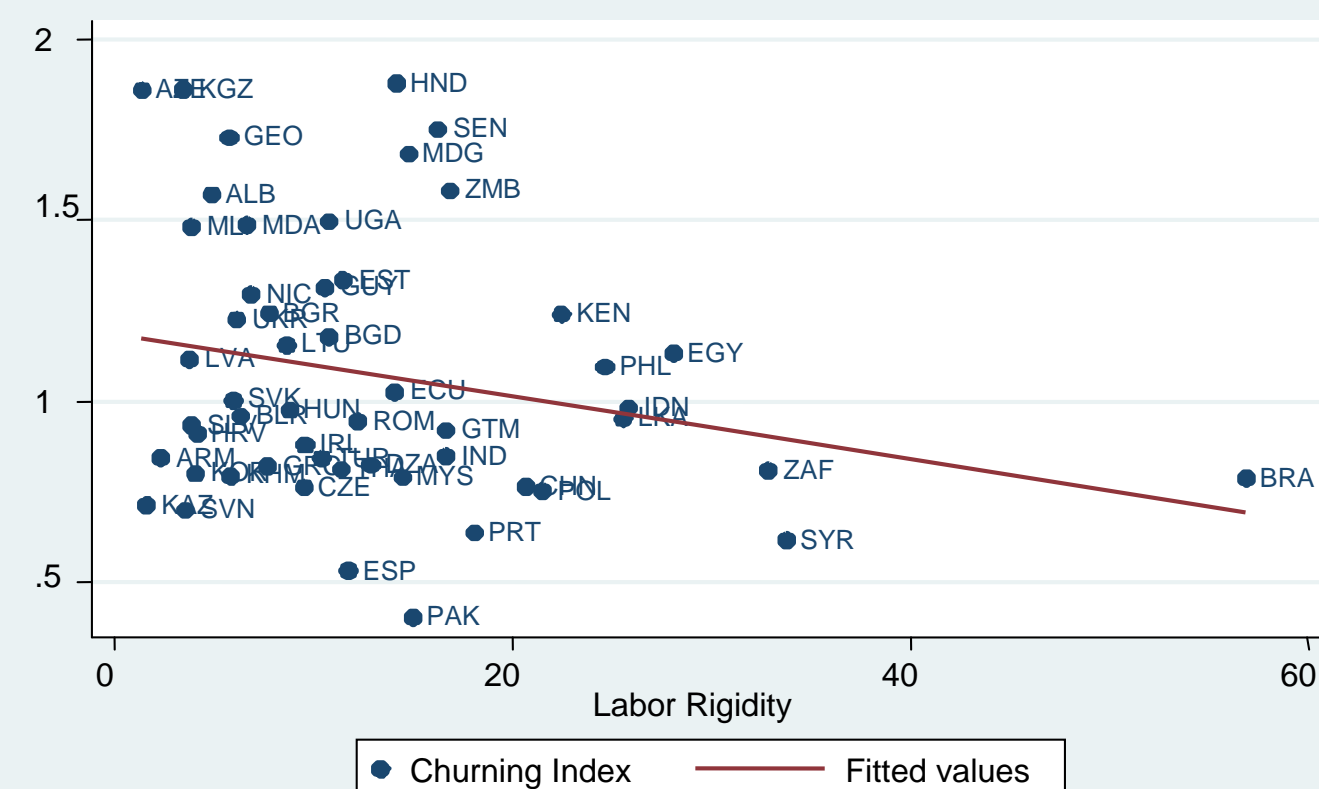

Figure 6: Trade Structure Churning vs Labor Market Rigidity, All Sectors The slope coefficient (standard error) $=-0.009(0.005), \mathrm{t}=-1.75$

Excluding Brazil, the slope coefficient (standard error) $=-0.010(0.006), \mathrm{t}=-1.60$

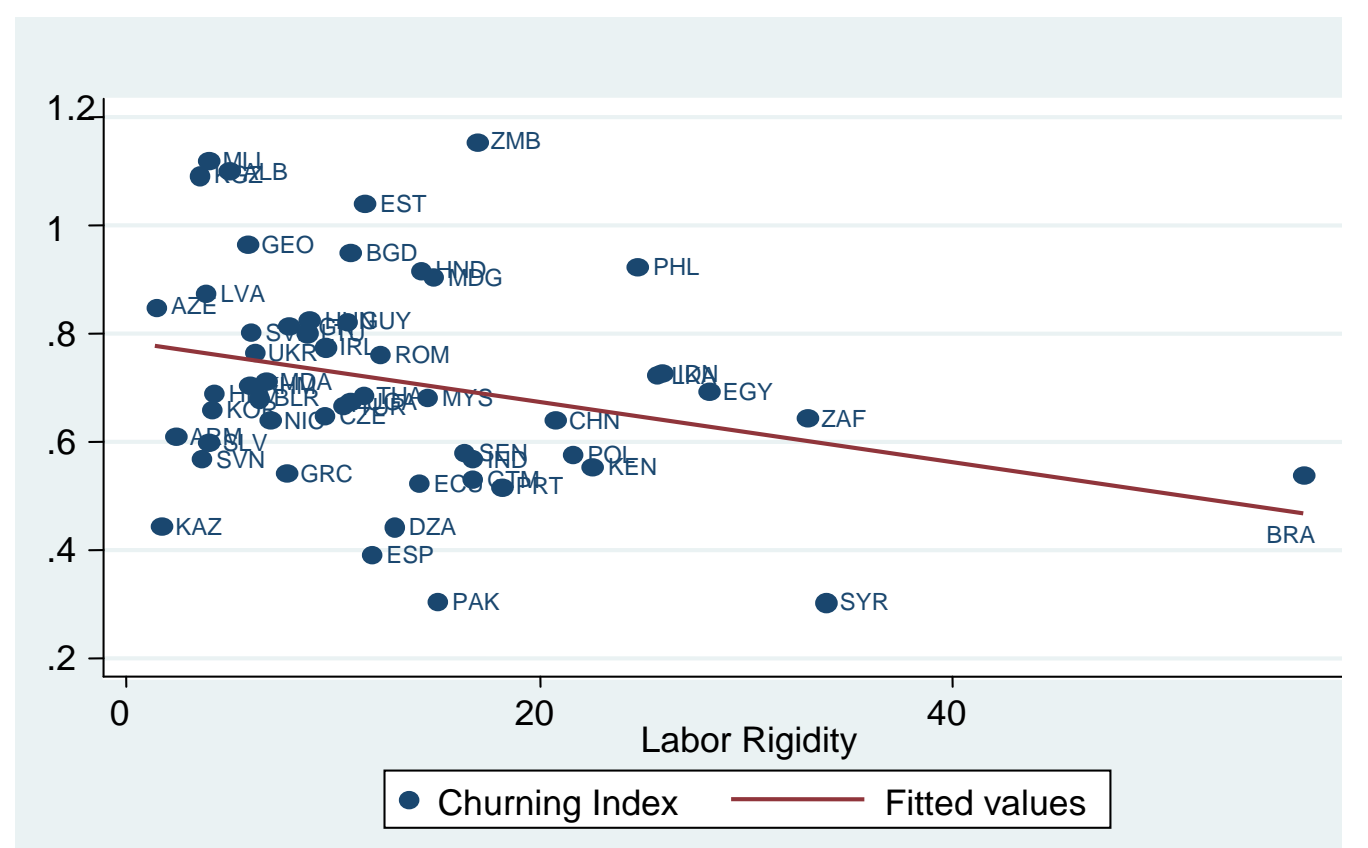

Figure 7: Trade Churning vs Labor Market Rigidity, Excluding Agriculture The slope coefficient (standard error) $=-0.0056(0.0026), \mathrm{t}=-2.11$ Excluding Brazil, the slope coefficient (standard error) $=-0.0065(0.0034), t=-1.94$ 


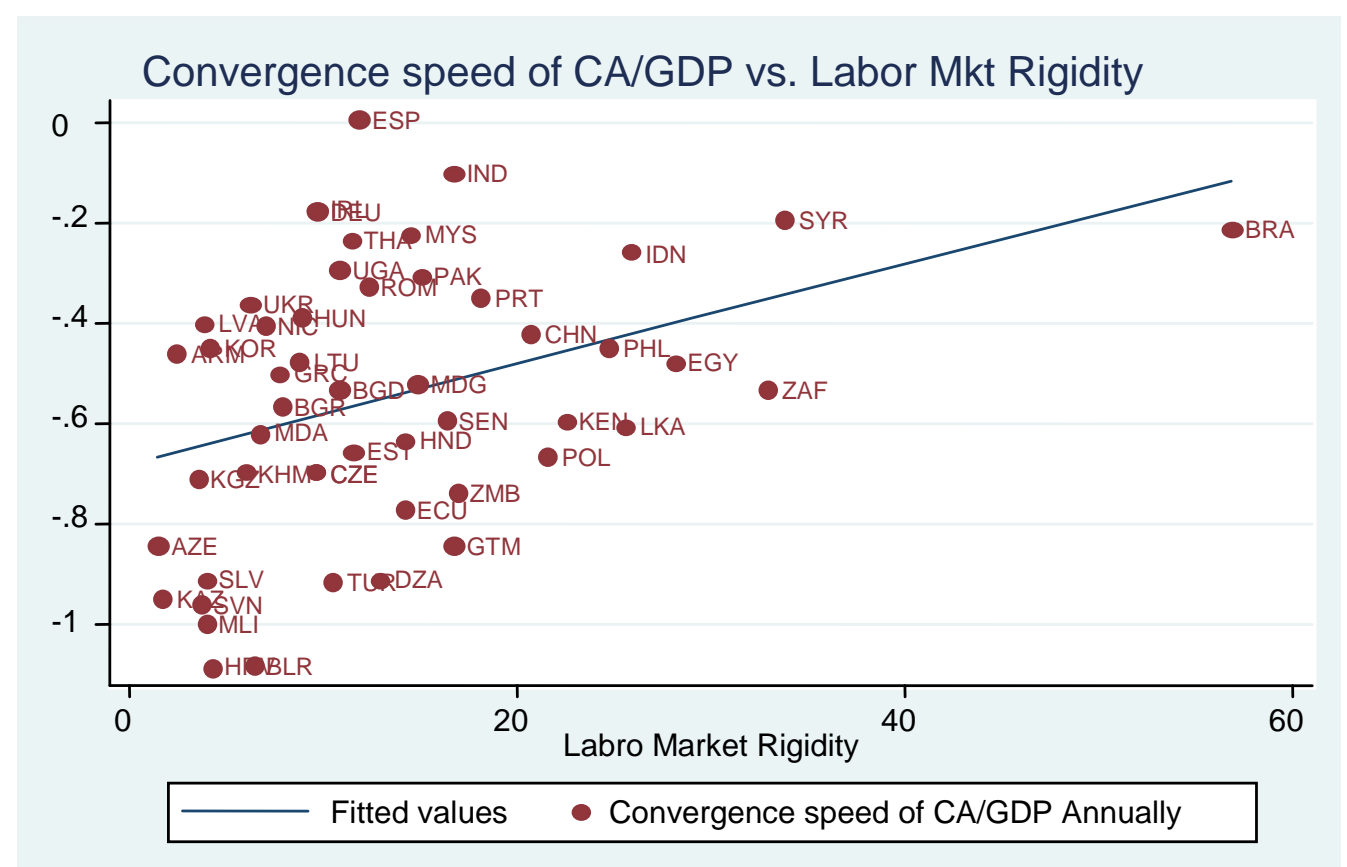

Figure 8: Convergence Speed of CA/GDP vs Labor Market Rigidity

(based on Column 1 of Table 3; Convergence speed estimated with annual data) The slope coefficient (standard error) $=1.012(0.350), t=2.90$ 


\section{Table 2: Comparing Savings and Investments Reponses to Shocks}

Main messages:

(a) The predictions from a two-sector model with a rigid labor market resemble those of the standard one-sector model.

(b) With a flexible labor market, no current account responses to either shock.

\begin{tabular}{|c|c|c|c|c|c|c|}
\hline Shock & $\begin{array}{l}\text { Labor } \\
\text { market }\end{array}$ & Variables & Q1 & $\mathrm{Q} 2$ & Q3 & Q4 \\
\hline \multirow[t]{8}{*}{ temporary } & flexible & $\mathrm{S}$ & 0.0310 & -0.0016 & -0.0015 & -0.0014 \\
\hline & & I & 0.0310 & -0.0016 & -0.0015 & -0.0014 \\
\hline & & $\mathrm{CA}$ & 0 & 0 & 0 & 0 \\
\hline & & $\mathrm{K}$ & 0.0310 & 0.0294 & 0.0279 & 0.0265 \\
\hline & rigid & $\mathrm{S}$ & 0.0310 & -0.0016 & -0.0015 & -0.0014 \\
\hline & & $\mathrm{I}$ & 0.0302 & -0.0015 & -0.0015 & -0.0014 \\
\hline & & $\mathrm{CA}$ & 0.0009 & 0.0001 & 0.0000 & 0.0000 \\
\hline & & $\mathrm{K}$ & 0.0302 & 0.0287 & 0.0272 & 0.0258 \\
\hline \multirow[t]{8}{*}{ persistent } & flexible & $\mathrm{S}$ & 0.0150 & 0.0127 & 0.0108 & 0.0090 \\
\hline & & I & 0.0150 & 0.0127 & 0.0108 & 0.0090 \\
\hline & & $\mathrm{CA}$ & 0 & 0 & 0 & 0 \\
\hline & & $\mathrm{K}$ & 0.0150 & 0.0277 & 0.0385 & 0.0475 \\
\hline & rigid & $\mathrm{S}$ & 0.0157 & 0.0133 & 0.0112 & 0.0094 \\
\hline & & I & 0.0624 & 0.0082 & 0.0067 & 0.0053 \\
\hline & & $\mathrm{CA}$ & -0.0467 & 0.0051 & 0.0045 & 0.0041 \\
\hline & & $\mathrm{K}$ & 0.0624 & 0.0706 & 0.0773 & 0.0836 \\
\hline
\end{tabular}

Note: All the values represent level deviations from steady state 
Table 3: Labor Market Rigidity and Convergence Speed of CA/GDP (with Convergence Speed Estimated with Quarterly Data)

\begin{tabular}{|l|c|cc|cc|cc|}
\hline & $\mathrm{b} 1 \mathrm{Q}$ & $\mathrm{b} 1 \mathrm{Q}$ & $\mathrm{b} 1 \mathrm{Q}$ & $\mathrm{b} 1 \mathrm{Q}$ & $\mathrm{b} 1 \mathrm{Q}$ & $\mathrm{b} 1 \mathrm{Q}$ & $\mathrm{b} 1 \mathrm{Q}$ \\
\hline Labor market rigidity & 1.063 & 1.174 & 1.16 & 1.214 & 1.192 & 1.108 & 1.077 \\
& $(0.536)^{*}$ & $(0.615)^{*}$ & $(0.621)^{*}$ & $(0.562)^{*}$ & $(0.566)^{*}$ & $(0.575)^{*}(0.585)^{*}$ \\
\hline Exchange rate: crawling peg & & -0.173 & -0.217 & -0.173 & -0.219 & & \\
& & $(0.20)$ & $(0.21)$ & $(0.19)$ & $(0.20)$ & \\
\hline Exchange rate: managed float & & -0.206 & -0.212 & & & \\
& & $(0.25)$ & $(0.25)$ & & & \\
\hline Exchange rate: float & & $($ dropped) & $($ dropped $)$ & & & \\
& & & & & & \\
\hline Exchange rate: free falling & & -0.257 & -0.239 & & & & \\
& & $(0.21)$ & $(0.21)$ & & & & \\
\hline Exchange rate: dual market & & -0.182 & -0.177 & & & & \\
& & $(0.41)$ & $(0.41)$ & & & & \\
\hline Exchange rate: managed float, float, free & & & & -0.24 & -0.229 & & \\
falling or dual market & & & & $(0.19)$ & $(0.19)$ & & \\
\hline Exchange rate: float & & & & & & -0.184 & -0.153 \\
& & & & & & $(0.14)$ & $(0.15)$ \\
\hline Exchange rate: intermediate & & & & & & 0.004 & 0.041 \\
& & & & & & $(0.18)$ & $(0.20)$ \\
\hline Log GDP / capita [10,000US\$] & & & 0.109 & & 0.112 & & 0.071 \\
& & & $(0.14)$ & & $(0.13)$ & & $(0.13)$ \\
\hline Constant & -0.57 & -0.405 & -0.437 & -0.408 & -0.441 & -0.491 & -0.54 \\
& $(0.090)^{*}$ & $(0.179)^{*}$ & $(0.185)^{*}$ & $(0.171)^{*}$ & $(0.177)^{*}(0.111)^{*}(0.144)^{*}$ \\
\hline Observations & 30 & 30 & 30 & 30 & 30 & 30 & 30 \\
R-squared & 0.12 & 0.18 & 0.2 & 0.17 & 0.2 & 0.2 & 0.21 \\
\hline
\end{tabular}

Standard errors in parentheses, * significant at $10 \%$

The dependent variable is a country-specific regression coefficient for an AR process with lags that characterizes the speed of convergence of the current account to its long run equilibrium

The exchange rate regime classifications used in columns 2-3 and 4-5 are based on Reinhart and Rogoff (2004). In columns 4-5, their last three classifications are combined. The exchange rate classifications in column 6-7 are based on Levy-Yeyati and Sturzenegger (2002) 
Table 4: Labor Market Rigidity and Convergence Speed of CA/GDP (with Convergence Speed Estimated with Annual Data)

\begin{tabular}{|c|c|c|c|c|c|c|c|}
\hline & b1A & b1A & b1A & b1A & b1A & b1A & b1A \\
\hline Labor market rigidity & $\begin{array}{c}1.012 \\
(0.350)^{*} \\
\end{array}$ & $\begin{array}{c}1.228 \\
(0.407)^{*} \\
\end{array}$ & $\begin{array}{c}1.258 \\
(0.396)^{*}\end{array}$ & $\begin{array}{c}1.133 \\
(0.381)^{*} \\
\end{array}$ & $\begin{array}{c}1.151 \\
(0.371)^{*} \\
\end{array}$ & $\begin{array}{c}0.969 \\
(0.383)^{*} \\
\end{array}$ & $\begin{array}{c}1.031 \\
(0.367)^{*} \\
\end{array}$ \\
\hline Exchange rate: crawling peg & & $\begin{array}{l}0.063 \\
(0.11) \\
\end{array}$ & $\begin{array}{l}0.024 \\
(0.11) \\
\end{array}$ & $\begin{array}{l}0.056 \\
(0.11) \\
\end{array}$ & $\begin{array}{l}0.015 \\
(0.11) \\
\end{array}$ & & \\
\hline Exchange rate: managed float & & $\begin{array}{l}-0.048 \\
(0.12)\end{array}$ & $\begin{array}{l}-0.036 \\
(0.12)\end{array}$ & & & & \\
\hline Exchange rate: float & & (dropped) & (dropped) & & & & \\
\hline Exchange rate: free falling & & $\begin{array}{l}-0.115 \\
(0.12)\end{array}$ & $\begin{array}{l}-0.096 \\
(0.12)\end{array}$ & & & & \\
\hline Exchange rate: dual market & & $\begin{array}{l}-0.235 \\
(0.29) \\
\end{array}$ & $\begin{array}{l}-0.245 \\
(0.28) \\
\end{array}$ & & & & \\
\hline $\begin{array}{l}\text { Exchange rate: managed float, float, free } \\
\text { falling or dual market }\end{array}$ & & & & $\begin{array}{l}-0.061 \\
(0.11)\end{array}$ & $\begin{array}{l}-0.037 \\
(0.11)\end{array}$ & & \\
\hline Exchange rate: float & & & & & & $\begin{array}{l}-0.028 \\
(0.08)\end{array}$ & $\begin{array}{l}-0.003 \\
(0.08)\end{array}$ \\
\hline Exchange rate: intermediate & & & & & & $\begin{array}{l}0.043 \\
(0.12) \\
\end{array}$ & $\begin{array}{c}0.07 \\
(0.11) \\
\end{array}$ \\
\hline Log GDP / capita [10,000US\$] & & & $\begin{array}{c}0.155 \\
(0.086)^{*} \\
\end{array}$ & & $\begin{array}{c}0.162 \\
(0.086)^{*} \\
\end{array}$ & & $\begin{array}{c}0.184 \\
(0.081)^{*} \\
\end{array}$ \\
\hline Constant & $\begin{array}{c}-0.689 \\
(0.059)^{*}\end{array}$ & $\begin{array}{c}-0.7 \\
(0.092)^{*}\end{array}$ & $\begin{array}{c}-0.747 \\
(0.093)^{*}\end{array}$ & $\begin{array}{c}-0.692 \\
(0.096)^{*}\end{array}$ & $\begin{array}{c}-0.745 \\
(0.097)^{*} \\
\end{array}$ & $\begin{array}{c}-0.678 \\
(0.070)^{*}\end{array}$ & $\begin{array}{c}-0.76 \\
(0.076)^{*}\end{array}$ \\
\hline $\begin{array}{l}\text { Observations } \\
\text { R-squared }\end{array}$ & $\begin{array}{c}49 \\
0.15 \\
\end{array}$ & $\begin{array}{c}47 \\
0.21 \\
\end{array}$ & $\begin{array}{c}47 \\
0.27 \\
\end{array}$ & $\begin{array}{c}47 \\
0.18 \\
\end{array}$ & $\begin{array}{c}47 \\
0.25 \\
\end{array}$ & $\begin{array}{c}47 \\
0.16 \\
\end{array}$ & $\begin{array}{c}47 \\
0.25 \\
\end{array}$ \\
\hline
\end{tabular}

Standard errors in parentheses, $*$ significant at $10 \%$

The dependent variable is a country-specific regression coefficient for an AR process with lags that characterizes the speed of convergence of the current account to its long run equilibrium

The exchange rate regime classifications used in columns 2-3 and 4-5 are based on Reinhart and Rogoff (2004). In columns 4-5, their last three classifications are combined. The exchange rate classifications in column 6-7 are based on Levy-Yeyati and Sturzenegger (2002) 
Table 5: Labor Rigidity and Standard Deviation of (Total trade/GDP)

\begin{tabular}{|c|c|c|c|c|c|c|c|c|}
\hline \multirow[b]{2}{*}{ Independent variables } & \multicolumn{4}{|c|}{ All observations } & \multicolumn{4}{|c|}{ Excluding BRA \& GUY \& MYS } \\
\hline & (1) & (2) & (3) & (4) & (5) & (6) & (7) & (8) \\
\hline Labor market rigidity & $\begin{array}{c}-0.325^{* *} \\
(0.154)\end{array}$ & $\begin{array}{c}-0.495^{* *} \\
(0.196)\end{array}$ & $\begin{array}{c}-0.329^{* *} \\
(0.157)\end{array}$ & $\begin{array}{c}-0.352^{* *} \\
(0.162)\end{array}$ & $\begin{array}{c}-0.435^{* * *} \\
(0.158)\end{array}$ & $\begin{array}{l}-0.462 * * * \\
(0.168)\end{array}$ & $\begin{array}{c}-0.440^{* *} \\
(0.163)\end{array}$ & $\begin{array}{c}-0.438^{* *} \\
(0.167)\end{array}$ \\
\hline Exchange rate: crawling peg & & $\begin{array}{l}3.032 \\
(3.856)\end{array}$ & $\begin{array}{c}2.207 \\
(3.861)\end{array}$ & & & $\begin{array}{c}0.829 \\
(3.352)\end{array}$ & $\begin{array}{c}0.608 \\
(3.294)\end{array}$ & \\
\hline Exchange rate: managed float & & $\begin{array}{l}-1.344 \\
(4.144)\end{array}$ & & & & $\begin{array}{l}-1.149 \\
(3.543)\end{array}$ & & \\
\hline Exchange rate: float & & $\begin{array}{c}-1.704 \\
(10.310)\end{array}$ & & & & $\begin{array}{l}-1.333 \\
(8.812)\end{array}$ & & \\
\hline Exchange rate: free falling & & $\begin{array}{c}6.644 \\
(4.602)\end{array}$ & & & & $\begin{array}{c}2.652 \\
(4.145)\end{array}$ & & \\
\hline Exchange rate: dual market & & $\begin{array}{c}25.25 \\
(16.870)\end{array}$ & & & & (dropped) & & \\
\hline $\begin{array}{l}\text { Exchange rate: managed float, } \\
\text { float, free falling or dual market }\end{array}$ & & & $\begin{array}{c}1.833 \\
(3.645)\end{array}$ & & & & $\begin{array}{c}0.183 \\
(3.076)\end{array}$ & \\
\hline Exchange rate: intermediate & & & & $\begin{array}{l}-4.63 \\
(4.468)\end{array}$ & & & & $\begin{array}{l}-2.475 \\
(3.773)\end{array}$ \\
\hline Exchange rate: float & & & & $\begin{array}{l}-2.274 \\
(3.348)\end{array}$ & & & & $\begin{array}{l}-0.231 \\
(2.842)\end{array}$ \\
\hline $\operatorname{sd}(\operatorname{lnCPI})$ & $\begin{array}{l}-0.471 \\
(0.741)\end{array}$ & $\begin{array}{l}-1.571 \\
(0.959)\end{array}$ & $\begin{array}{l}-0.518 \\
(0.766)\end{array}$ & $\begin{array}{l}-0.237 \\
(0.811)\end{array}$ & $\begin{array}{l}-0.429 \\
(0.741)\end{array}$ & $\begin{array}{l}-0.745 \\
(0.847)\end{array}$ & $\begin{array}{l}-0.442 \\
(0.767)\end{array}$ & $\begin{array}{l}-0.352 \\
(0.796)\end{array}$ \\
\hline $\operatorname{sd}(\operatorname{lnGDP}) /$ mean $(\operatorname{lnGDP})$ & $\begin{array}{c}4.064 \\
(21.370)\end{array}$ & $\begin{array}{c}7.335 \\
(22.430)\end{array}$ & $\begin{array}{c}7.672 \\
(22.570)\end{array}$ & $\begin{array}{c}6.628 \\
(22.300)\end{array}$ & $\begin{array}{c}6.072 \\
(17.800)\end{array}$ & $\begin{array}{c}7.159 \\
(19.180)\end{array}$ & $\begin{array}{c}6.727 \\
(18.850)\end{array}$ & $\begin{array}{c}6.569 \\
(18.700)\end{array}$ \\
\hline Constant & $\begin{array}{c}21.95 * * * \\
(2.703)\end{array}$ & $\begin{array}{c}23.22 * * * \\
(4.235)\end{array}$ & $\begin{array}{c}20.37 * * * \\
(3.822)\end{array}$ & $\begin{array}{c}23.30^{* * *} \\
(3.160)\end{array}$ & $\begin{array}{c}21.81 * * * \\
(2.763)\end{array}$ & $\begin{array}{c}22.08^{* * *} \\
(3.631)\end{array}$ & $\begin{array}{c}21.58^{* * *} \\
(3.538)\end{array}$ & $\begin{array}{c}22.10^{* * *} \\
(3.221)\end{array}$ \\
\hline Observations & 51 & 51 & 51 & 49 & 48 & 48 & 48 & 46 \\
\hline R-squared & 0.129 & 0.21 & 0.136 & 0.149 & 0.159 & 0.177 & 0.16 & 0.161 \\
\hline
\end{tabular}

Standard errors in parentheses, $* *$ significant at $5 \%, * * *$ significant at $1 \%$

The dependent variable is the country-specific standard deviation of (Import+Export)/GDP for the period from 1980 to 2005 (or all years for which data is available within this period)

The exchange rate regime classifications used in columns 2-3 and 6-7 are based on Reinhart and Rogoff (2004). In columns 3 and 7, their last 3 classification are combined. The exchange rate classification in column 4 and 8 are based on Levy-Yeyati and Sturzenegger (2002)

$\mathrm{sd}(\mathrm{lnCPI})$ is the standard deviation of the natural log of the Consumer Price Index and sd(lnGDP)/mean(lnGDP) is the standard deviation of the natural log of GDP divided by the mean of the natural log of GDP for each country over the period from 1980 to 2005. 
Table 6: Labor Rigidity and Standard Deviation of (CA/Total Trade)

\begin{tabular}{|c|c|c|c|c|c|c|c|c|}
\hline & all obs & all obs & all obs & all obs & excl. BRA \& NIC & excl. BRA \& NIC & exc1. BRA \& NIC & excl. BRA \& NIC \\
\hline Labor market rigidity & $\begin{array}{c}13.712 \\
(6.511)^{*}\end{array}$ & $\begin{array}{c}15.745 \\
(7.403)^{*}\end{array}$ & $\begin{array}{c}12.176 \\
(6.565)^{*}\end{array}$ & $\begin{array}{c}12.509 \\
(6.795)^{*}\end{array}$ & $\begin{array}{c}14.518 \\
(6.215)^{*}\end{array}$ & $\begin{array}{c}15.151 \\
(7.170)^{*}\end{array}$ & $\begin{array}{c}12.93 \\
(6.421)^{*}\end{array}$ & $\begin{array}{c}13.39 \\
(6.312)^{*}\end{array}$ \\
\hline Exchange rate: crawling peg & & $\begin{array}{l}6.433 \\
(9.83) \\
\end{array}$ & $\begin{array}{r}7.068 \\
(10.01) \\
\end{array}$ & & & $\begin{array}{l}8.015 \\
(9.29) \\
\end{array}$ & $\begin{array}{l}7.478 \\
(9.51) \\
\end{array}$ & \\
\hline Exchange rate: managed float & & $\begin{array}{c}6.111 \\
(10.98) \\
\end{array}$ & & & & $\begin{array}{c}6.691 \\
(10.48) \\
\end{array}$ & & \\
\hline Exchange rate: float & & $\begin{array}{c}31.874 \\
(17.144)^{*}\end{array}$ & & & & $\begin{array}{c}28.188 \\
(16.090)^{*}\end{array}$ & & \\
\hline Exchange rate: free falling & & $\begin{array}{l}14.226 \\
(16.35)\end{array}$ & & & & $\begin{array}{c}5.148 \\
(15.92)\end{array}$ & & \\
\hline Exchange rate: dual market & & $\begin{array}{l}-0.282 \\
(23.12) \\
\end{array}$ & & & & $\begin{array}{c}2.106 \\
(21.66) \\
\end{array}$ & & \\
\hline $\begin{array}{l}\text { Exchange rate: managed float, } \\
\text { float, free falling or dual market }\end{array}$ & & & $\begin{array}{l}14.701 \\
(10.10)\end{array}$ & & & & $\begin{array}{c}8.405 \\
(10.16)\end{array}$ & \\
\hline Exchange rate: float & & & & $\begin{array}{l}1.746 \\
(7.56)\end{array}$ & & & & $\begin{array}{l}-0.668 \\
(6.92)\end{array}$ \\
\hline Exchange rate: intermediate & & & & $\begin{array}{c}1.653 \\
(11.54) \\
\end{array}$ & & & & $\begin{array}{l}13.815 \\
(11.48) \\
\end{array}$ \\
\hline $\operatorname{sd}(\operatorname{lnCPI})$ & $\begin{array}{c}9.551 \\
(1.943)^{*} \\
\end{array}$ & $\begin{array}{c}9.944 \\
(2.083)^{*} \\
\end{array}$ & $\begin{array}{c}9.475 \\
(1.934)^{*} \\
\end{array}$ & $\begin{array}{c}9.665 \\
(2.097)^{*} \\
\end{array}$ & $\begin{array}{l}-4.038 \\
(5.18) \\
\end{array}$ & $\begin{array}{l}-3.484 \\
(5.68) \\
\end{array}$ & $\begin{array}{l}-3.271 \\
(5.50) \\
\end{array}$ & $\begin{array}{l}-6.571 \\
(5.69) \\
\end{array}$ \\
\hline $\operatorname{sd}(\ln G D P) /$ mean $(\ln G D P)$ & $\begin{array}{c}-125.662 \\
(84.62) \\
\end{array}$ & $\begin{array}{l}-181.012 \\
(134.70) \\
\end{array}$ & $\begin{array}{l}-168.784 \\
(91.116)^{*}\end{array}$ & $\begin{array}{c}-125.979 \\
(91.36) \\
\end{array}$ & $\begin{array}{l}218.668 \\
(143.98) \\
\end{array}$ & $\begin{array}{l}222.032 \\
(201.53) \\
\end{array}$ & $\begin{array}{l}178.874 \\
(169.61) \\
\end{array}$ & $\begin{array}{c}289.532 \\
(158.596)^{*}\end{array}$ \\
\hline Constant & $\begin{array}{c}44.657 \\
(6.065)^{*}\end{array}$ & $\begin{array}{c}38.278 \\
(8.855)^{*}\end{array}$ & $\begin{array}{c}37.781 \\
(8.623)^{*}\end{array}$ & $\begin{array}{c}43.566 \\
(6.792)^{*} \\
\end{array}$ & $\begin{array}{c}40.204 \\
(6.377)^{*}\end{array}$ & $\begin{array}{c}32.043 \\
(8.898)^{*}\end{array}$ & $\begin{array}{c}35.26 \\
(8.464)^{*} \\
\end{array}$ & $\begin{array}{c}38.064 \\
(6.901)^{*}\end{array}$ \\
\hline $\begin{array}{l}\text { Observations } \\
\text { R-squared }\end{array}$ & $\begin{array}{c}42 \\
0.46 \\
\end{array}$ & $\begin{array}{c}41 \\
0.53 \\
\end{array}$ & $\begin{array}{l}41 \\
0.5\end{array}$ & $\begin{array}{c}41 \\
0.47 \\
\end{array}$ & $\begin{array}{c}40 \\
0.19 \\
\end{array}$ & $\begin{array}{c}39 \\
0.26 \\
\end{array}$ & $\begin{array}{l}39 \\
0.2 \\
\end{array}$ & $\begin{array}{c}39 \\
0.22 \\
\end{array}$ \\
\hline
\end{tabular}

Standard errors in parentheses, * significant at $10 \%$

The dependent variable is the country-specific standard deviation of Current Account / trade for the period from 1980 to 2005 (or all years for which data is available within this period)

The exchange rate regime classifications used in columns 2-3 and 6-7 are based on Reinhart and Rogoff (2004). In columns 3 and 7, their last three classifications are combined. The exchange rate classifications in column 4 and 8 are based on Levy-Yeyati and Sturzenegger (2002)

$\operatorname{sd}(\operatorname{lnCPI})$ is the standard deviation of the natural log of the Consumer Price Index and $\operatorname{sd}(\operatorname{lnGDP}) /$ mean $(\operatorname{lnGDP})$ is the standard deviation of the natural $\log$ of GDP divided by the mean of the natural $\log$ of GDP for each country over the period from 1980 to 2005. 
Figure A1: Impulse response to a temporary beta shock without labor market frictions
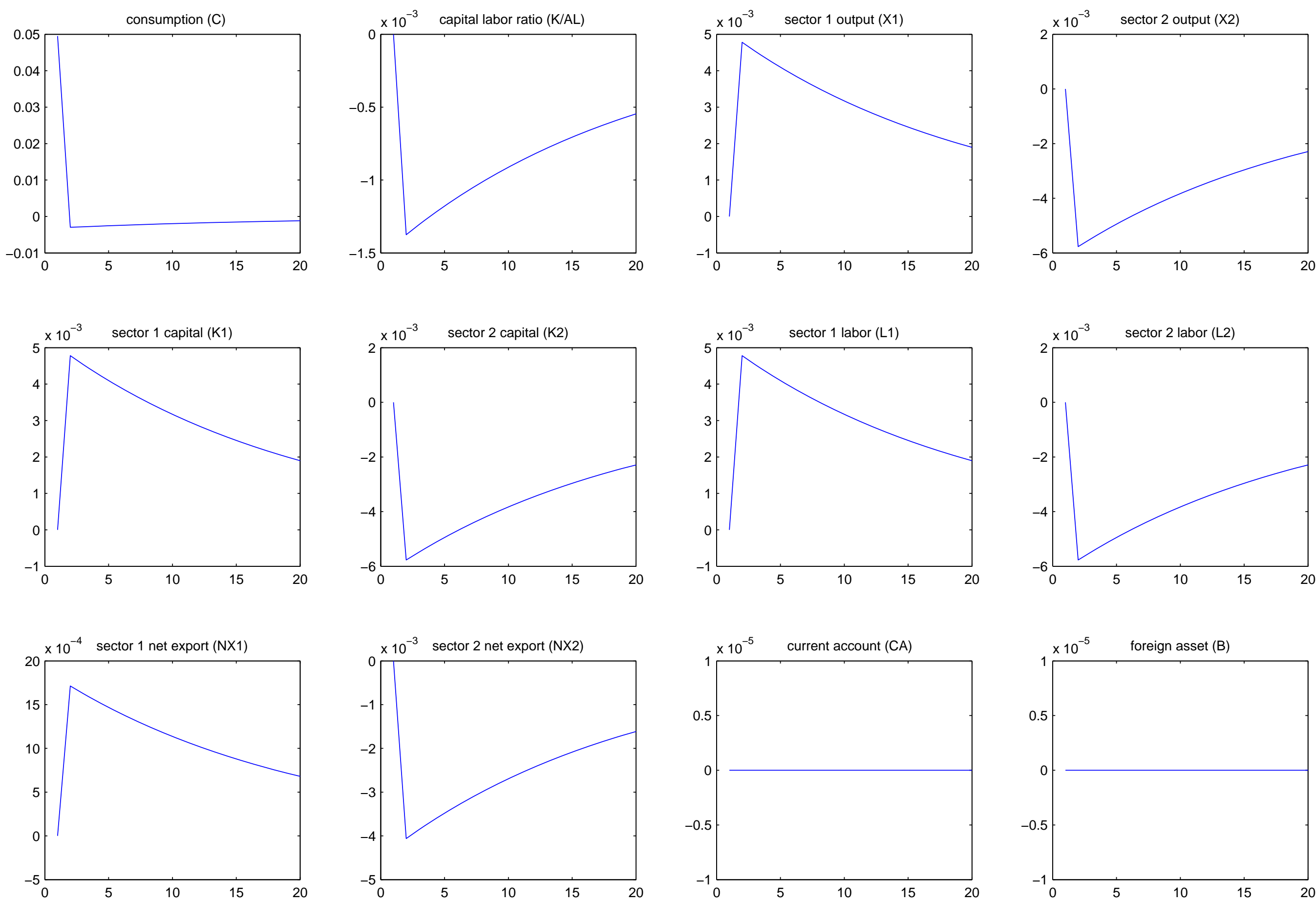
Figure A2: Impulse response to a temporary beta shock with labor market frictions
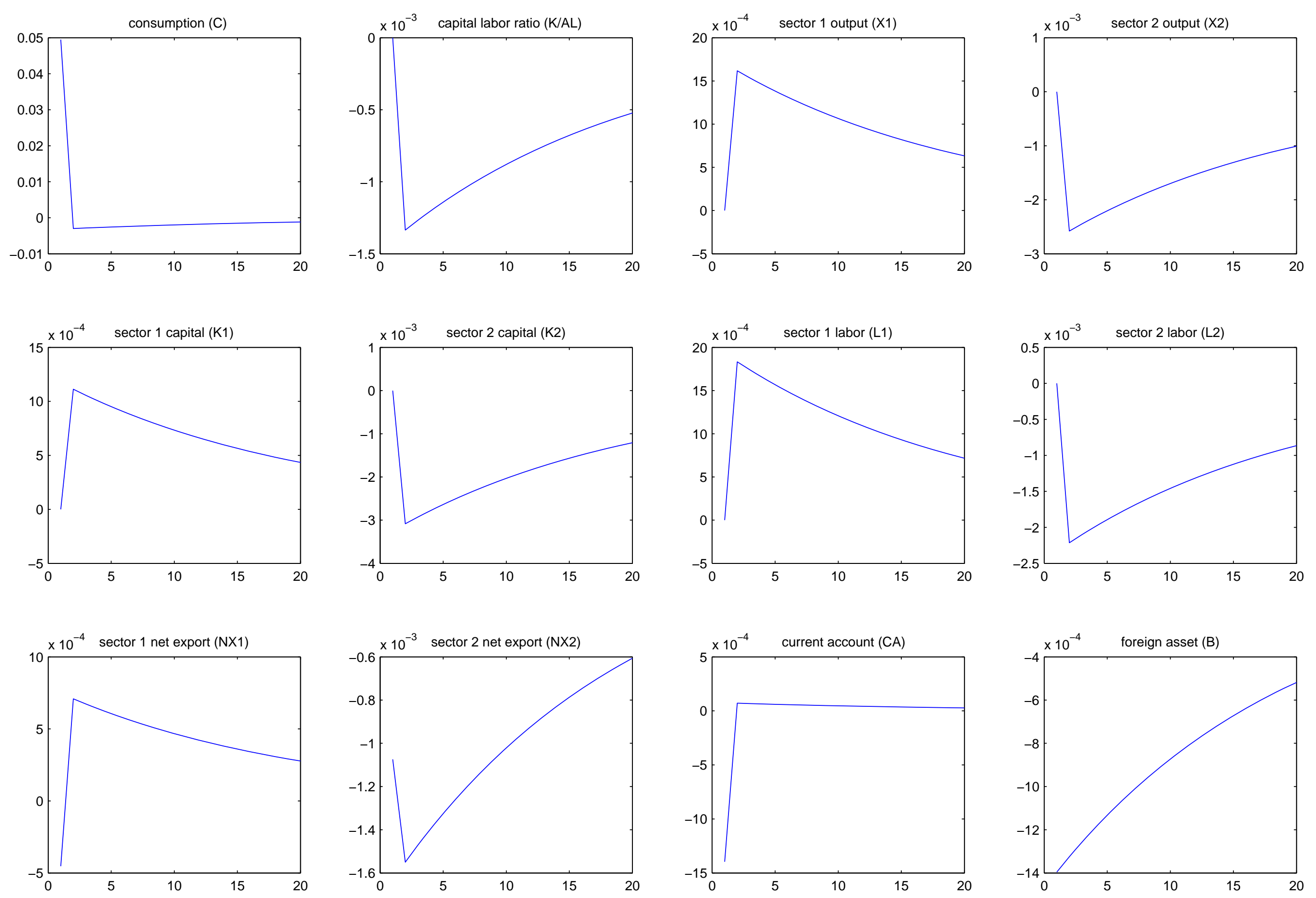
Figure A3: Impulse response to a persistent beta shock without labor market frictions
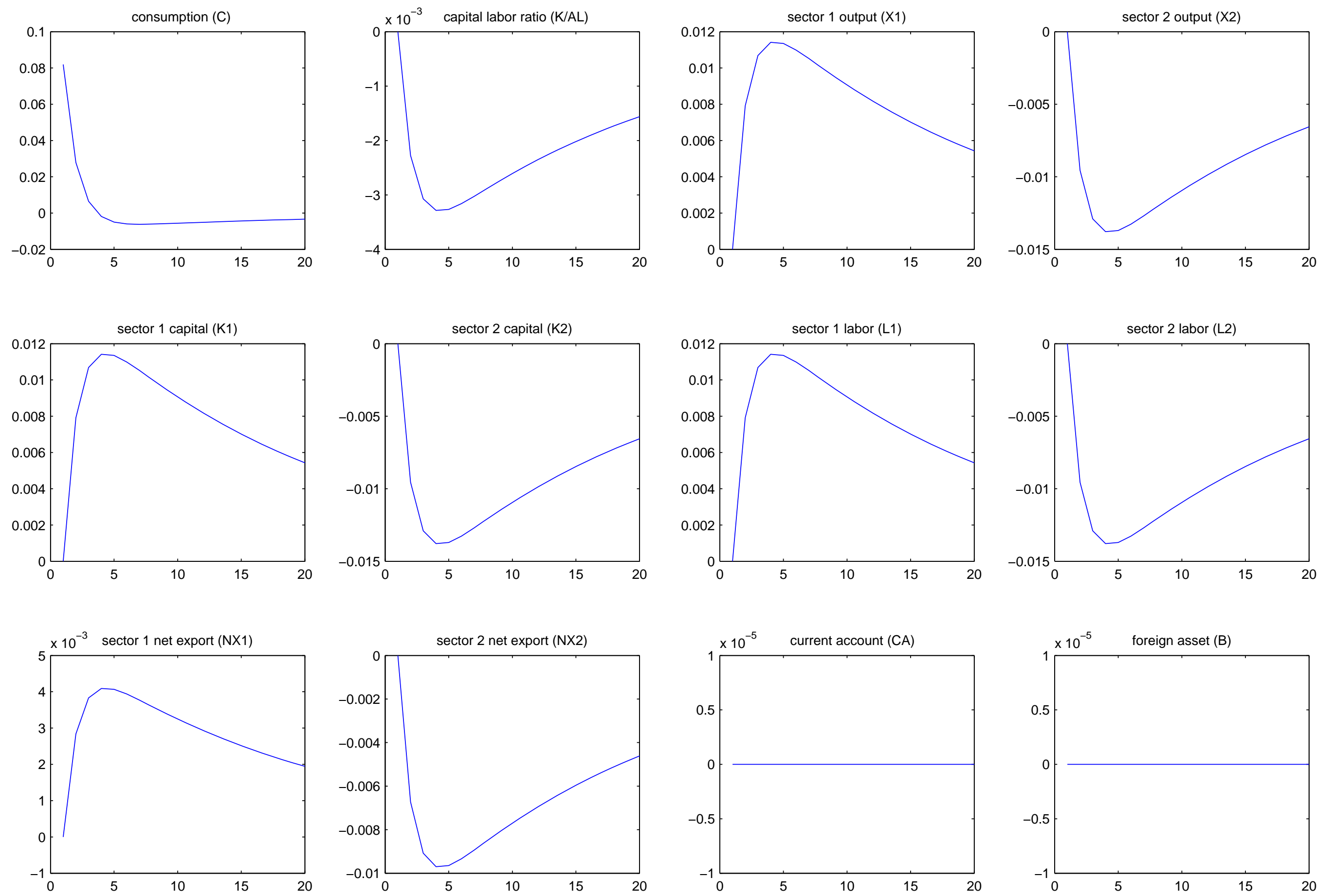
Figure A4: Impulse response to a persistent beta shock with labor market frictions
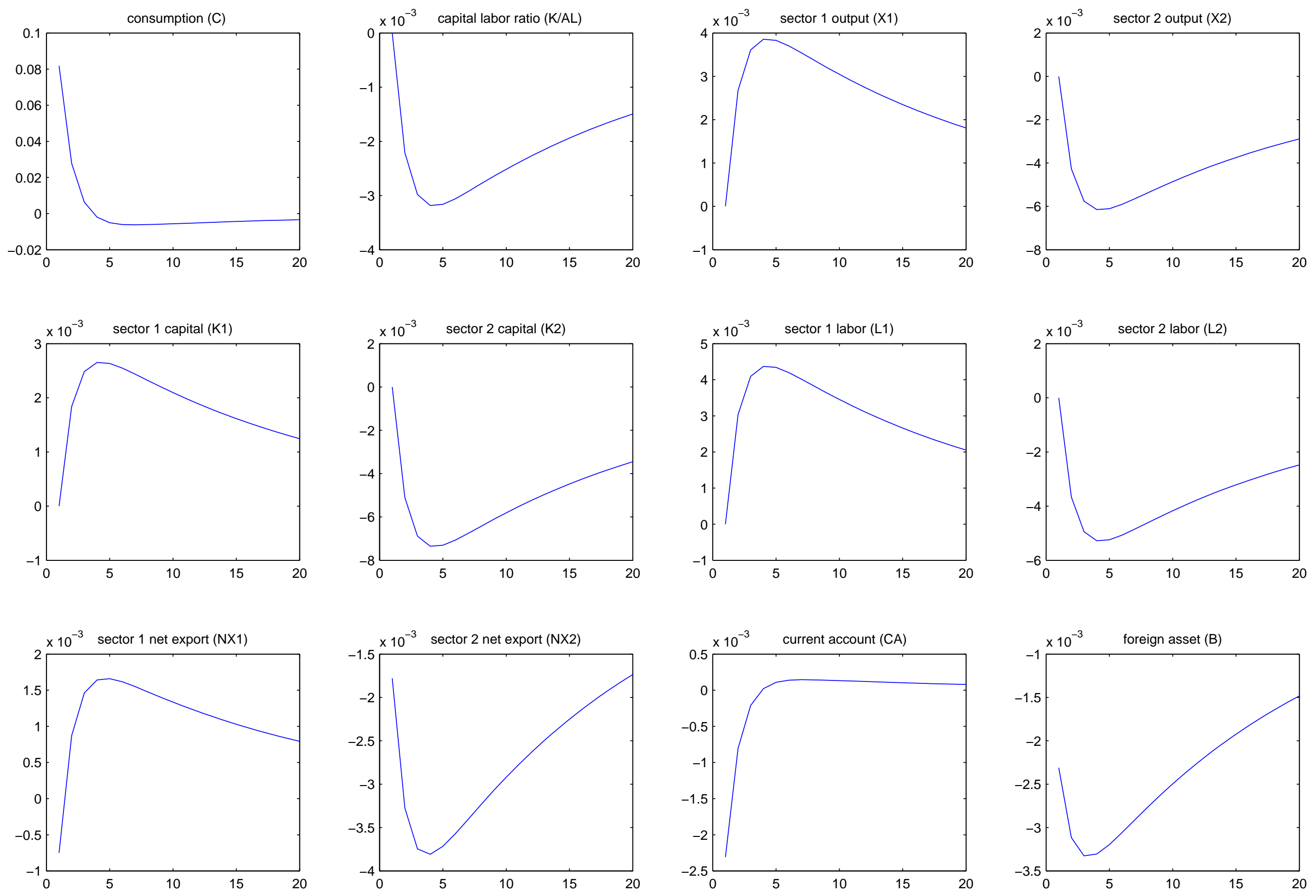
Figure A5: The Case of a Beta Shock
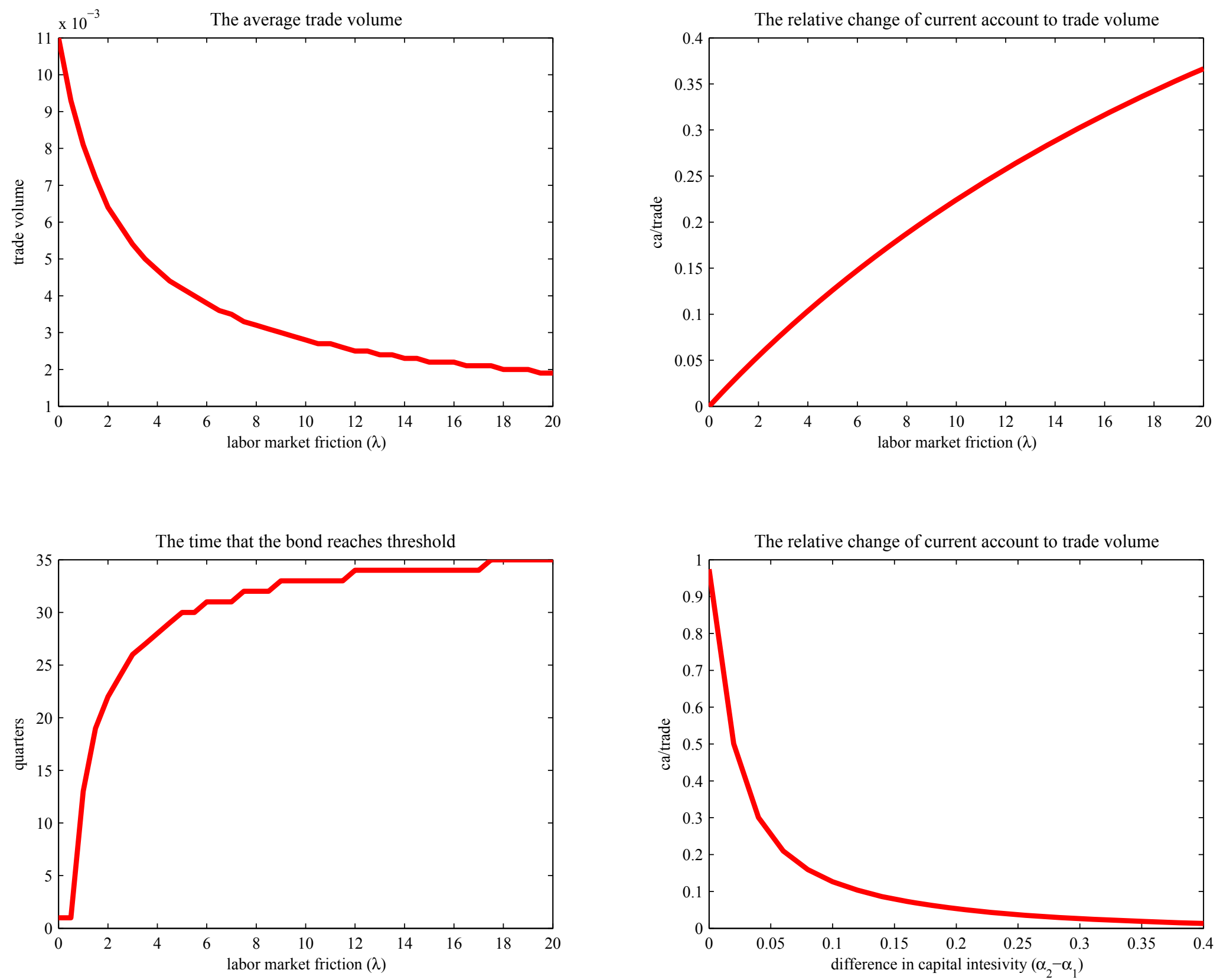
Not for publication

Table A1: Labor Market Rigidity and Trade Structure Churning Index

\begin{tabular}{|c|c|c|c|c|}
\hline $\begin{array}{c}\text { Country Code } \\
1\end{array}$ & $\begin{array}{c}\text { Country Name } \\
2\end{array}$ & $\begin{array}{c}\text { Trade Structure } \\
\text { Churning } \\
\text { All sector } \\
3 \\
\end{array}$ & $\begin{array}{c}\text { Trade Structure } \\
\text { Churning Excluding } \\
\text { Agriculture } \\
4\end{array}$ & $\begin{array}{c}\text { Labor Market } \\
\text { Rigidity } \\
5\end{array}$ \\
\hline$\overline{\mathrm{ALB}}$ & Albania & 1.57 & 1.10 & 4.90 \\
\hline ARM & Armenia & 0.84 & 0.61 & 2.35 \\
\hline AZE & Azerbaijan, Rep. of & 1.86 & 0.85 & 1.40 \\
\hline BGD & Bangladesh & 1.18 & 0.95 & 10.80 \\
\hline BGR & Bulgaria & 1.24 & 0.81 & 7.80 \\
\hline BLR & Belarus & 0.96 & 0.68 & 6.35 \\
\hline BRA & Brazil & 0.79 & 0.54 & 56.90 \\
\hline $\mathrm{CHN}$ & China & 0.76 & 0.64 & 20.70 \\
\hline CZE & Czech Republic & 0.76 & 0.65 & 9.55 \\
\hline DZA & Algeria & 0.82 & 0.44 & 12.90 \\
\hline ECU & Ecuador & 1.02 & 0.52 & 14.10 \\
\hline EGY & Egypt & 1.13 & 0.69 & 28.10 \\
\hline ESP & Spain & 0.53 & 0.39 & 11.80 \\
\hline EST & Estonia & 1.33 & 1.04 & 11.50 \\
\hline GEO & Georgia & 1.73 & 0.96 & 5.80 \\
\hline GRC & Greece & 0.82 & 0.54 & 7.70 \\
\hline GTM & Guatemala & 0.92 & 0.53 & 16.70 \\
\hline GUY & Guyana & 1.31 & 0.82 & 10.60 \\
\hline HND & Honduras & 1.88 & 0.92 & 14.20 \\
\hline HRV & Croatia & 0.91 & 0.69 & 4.20 \\
\hline HUN & Hungary & 0.97 & 0.83 & 8.80 \\
\hline IDN & Indonesia & 0.98 & 0.73 & 25.90 \\
\hline IND & India & 0.85 & 0.57 & 16.70 \\
\hline IRL & Ireland & 0.88 & 0.78 & 9.60 \\
\hline KAZ & Kazakhstan & 0.71 & 0.44 & 1.65 \\
\hline KEN & Kenya & 1.24 & 0.55 & 22.50 \\
\hline KGZ & Kyrgyz Republic & 1.86 & 1.09 & 3.50 \\
\hline KHM & Cambodia & 0.79 & 0.71 & 5.90 \\
\hline KOR & Korea & 0.80 & 0.66 & 4.10 \\
\hline LKA & Sri Lanka & 0.95 & 0.72 & 25.60 \\
\hline LTU & Lithuania & 1.15 & 0.80 & 8.70 \\
\hline LVA & Latvia & 1.12 & 0.88 & 3.80 \\
\hline MDA & Moldova & 1.49 & 0.71 & 6.70 \\
\hline MDG & Madagascar & 1.69 & 0.90 & 14.80 \\
\hline MLI & Mali & 1.48 & 1.12 & 3.90 \\
\hline MYS & Malaysia & 0.79 & 0.68 & 14.50 \\
\hline NIC & Nicaragua & 1.29 & 0.64 & 6.90 \\
\hline PAK & Pakistan & 0.40 & 0.30 & 15.00 \\
\hline
\end{tabular}




\begin{tabular}{llccc} 
PHL & Philippines & 1.09 & 0.92 & 24.70 \\
POL & Poland & 0.75 & 0.58 & 21.55 \\
PRT & Portugal & 0.63 & 0.52 & 18.10 \\
ROM & Romania & 0.94 & 0.76 & 12.25 \\
SEN & Senegal & 1.75 & 0.58 & 16.30 \\
SLV & El Salvador & 0.93 & 0.60 & 3.90 \\
SVK & Slovakia & 1.00 & 0.80 & 6.00 \\
SVN & Slovenia & 0.70 & 0.57 & 3.60 \\
SYR & Syrian Arab Republic & 0.61 & 0.30 & 33.80 \\
THA & Thailand & 0.81 & 0.69 & 11.40 \\
TUR & Turkey & 0.84 & 0.67 & 10.45 \\
UGA & Uganda & 1.50 & 0.67 & 10.80 \\
UKR & Ukraine & 1.23 & 0.76 & 6.15 \\
VNM & Vietnam & No data & No data & 10.90 \\
ZAF & South Africa & 0.81 & 0.65 & 32.90 \\
ZMB & Zambia & 1.58 & 1.16 & 16.90 \\
\hline
\end{tabular}

\section{Sources:}

1. Trade Structure Churning Indexes are computed by the authors using most disaggregated data available on exports and imports from the United Nations' Comtrade database at the HS 6 digit level. Let $s^{\mathrm{x}}(\mathrm{j}, \mathrm{k}, \mathrm{t})=$ share of product $\mathrm{k}$ in country's exports in year $\mathrm{t}$, and $\mathrm{s}^{\mathrm{M}}(\mathrm{j}, \mathrm{k}, \mathrm{t})=$ share of product k in country j's imports in year t. Then the Trade Structure Churning Index for country $j$, or Churning(j) for short, is defined by

Churning $(j)=1 / T \sum_{t} \sum_{k}\left[\left|s^{X}(j, k, t)-s^{X}(j, k, t-2)\right|+\left|s^{M}(j, k, t)-s^{M}(j, k, t-2)\right|\right]$

Where $t=1996,1998,2000,2002$, and 2004, and $\mathrm{T}=5$. The churning index is bounded between zero (no change in trade structure) and 2 (maximum possible change).

Column 3 is computed using data for all HS sectors. Column 4 is computed excluding HS Chapters 1-29 (i.e., excluding agriculture, dairy, fishery and related sectors).

2. Labor Market Rigidity (Column 5) refers to the fraction of managers who report labor regulations as either a major business constraint or a severe business constraint in a World Bank Investment Climate Assessment survey conducted in 2002. This should be regarded as a de facto measure of labor market rigidity. 


\section{Not for publication}

Table A2: Labor Market Rigidity and Current Account Convergence (with CA/GDP convergence speed estimated from a TAR model, quarterly data)

\begin{tabular}{|c|c|c|c|c|c|c|c|}
\hline & $\mathrm{b} 1 \mathrm{Q}$ & $\mathrm{b} 1 \mathrm{Q}$ & $\mathrm{b} 1 \mathrm{Q}$ & b1Q & b1Q & b1Q & b1Q \\
\hline Labor market rigidity & $\begin{array}{c}0.93 \\
(0.464)^{*} \\
\end{array}$ & $\begin{array}{c}1.008 \\
(0.527)^{*} \\
\end{array}$ & $\begin{array}{c}0.987 \\
(0.518)^{*} \\
\end{array}$ & $\begin{array}{c}1.038 \\
(0.485)^{*}\end{array}$ & $\begin{array}{c}1.004 \\
(0.474)^{*} \\
\end{array}$ & $\begin{array}{c}1.04 \\
(0.512)^{*} \\
\end{array}$ & $\begin{array}{c}0.989 \\
(0.514)^{*} \\
\end{array}$ \\
\hline Exchange rate: crawling peg & & $\begin{array}{l}-0.183 \\
(0.17)\end{array}$ & $\begin{array}{l}-0.248 \\
(0.17)\end{array}$ & $\begin{array}{l}-0.183 \\
(0.16)\end{array}$ & $\begin{array}{l}-0.251 \\
(0.17)\end{array}$ & & \\
\hline Exchange rate: managed float & & $\begin{array}{l}-0.126 \\
(0.21)\end{array}$ & $\begin{array}{l}-0.136 \\
(0.21) \\
\end{array}$ & & & & \\
\hline Exchange rate: float & & (dropped) & (dropped) & & & & \\
\hline Exchange rate: free falling & & $\begin{array}{l}-0.248 \\
(0.18)\end{array}$ & $\begin{array}{l}-0.221 \\
(0.18)\end{array}$ & & & & \\
\hline Exchange rate: dual market & & $\begin{array}{l}-0.198 \\
(0.35)\end{array}$ & $\begin{array}{l}-0.191 \\
(0.34) \\
\end{array}$ & & & & \\
\hline $\begin{array}{l}\text { Exchange rate: managed float, float, free } \\
\text { falling or dual market }\end{array}$ & & & & $\begin{array}{l}-0.212 \\
(0.16)\end{array}$ & $\begin{array}{l}-0.195 \\
(0.16)\end{array}$ & & \\
\hline Exchange rate: float & & & & & & $\begin{array}{l}-0.109 \\
(0.12) \\
\end{array}$ & $\begin{array}{l}-0.057 \\
(0.13) \\
\end{array}$ \\
\hline Exchange rate: intermediate & & & & & & $\begin{array}{l}-0.074 \\
(0.16) \\
\end{array}$ & $\begin{array}{l}-0.012 \\
(0.17) \\
\end{array}$ \\
\hline Log GDP / capita [10,000US\$] & & & $\begin{array}{c}0.16 \\
(0.12) \\
\end{array}$ & & $\begin{array}{l}0.169 \\
(0.11) \\
\end{array}$ & & $\begin{array}{l}0.117 \\
(0.11) \\
\end{array}$ \\
\hline Constant & $\begin{array}{c}-0.6 \\
(0.077)^{*} \\
\end{array}$ & $\begin{array}{c}-0.439 \\
(0.153)^{*}\end{array}$ & $\begin{array}{c}-0.487 \\
(0.155)^{*}\end{array}$ & $\begin{array}{c}-0.441 \\
(0.148)^{*}\end{array}$ & $\begin{array}{c}-0.491 \\
(0.148)^{*}\end{array}$ & $\begin{array}{c}-0.548 \\
(0.099)^{*} \\
\end{array}$ & $\begin{array}{c}-0.629 \\
(0.126)^{*}\end{array}$ \\
\hline Observations & 30 & 30 & 30 & 30 & 30 & 30 & 30 \\
\hline R-squared & 0.13 & 0.2 & 0.26 & 0.18 & 0.25 & 0.15 & 0.19 \\
\hline
\end{tabular}

Standard errors in parentheses, * significant at $10 \%$

The dependent variable is a country-specific regression coefficient for a symmetric treshold AR process that characterizes the speed of convergence of the current account to its long run equilibrium

The exchange rate regime classifications used in columns 2-3 and 4-5 are based on Reinhart and Rogoff (2004). In columns 4-5, their last three classifications are combined. The exchange rate classifications in column 6-7 are based on Levy-Yeyati and Sturzenegger (2002) 


\section{Not for publication}

\section{Table A3: Labor Market Rigidity and Current Account Convergence:}

(with CA/GDP convergence speed estimated with a TAR model, annual data)

\begin{tabular}{|c|c|c|c|c|c|c|c|}
\hline & $\mathrm{b} 1 \mathrm{~A}$ & $\mathrm{~b} 1 \mathrm{~A}$ & $\mathrm{~b} 1 \mathrm{~A}$ & $\mathrm{~b} 1 \mathrm{~A}$ & b1A & $\mathrm{b} 1 \mathrm{~A}$ & b1A \\
\hline Labor market rigidity & $\begin{array}{c}0.96 \\
(0.505)^{*}\end{array}$ & $\begin{array}{c}0.99 \\
(0.565)^{*}\end{array}$ & $\begin{array}{c}1.049 \\
(0.548)^{*}\end{array}$ & $\begin{array}{c}1.162 \\
(0.554)^{*}\end{array}$ & $\begin{array}{c}1.204 \\
(0.534)^{*} \\
\end{array}$ & $\begin{array}{r}0.937 \\
(0.590) \\
\end{array}$ & $\begin{array}{c}1.052 \\
(0.556)^{*} \\
\end{array}$ \\
\hline Exchange rate: crawling peg & & $\begin{array}{l}0.063 \\
(0.16)\end{array}$ & $\begin{array}{l}0.032 \\
(0.16)\end{array}$ & $\begin{array}{l}0.041 \\
(0.18)\end{array}$ & $\begin{array}{l}-0.004 \\
(0.17)\end{array}$ & & \\
\hline Exchange rate: managed float & & $\begin{array}{l}0.013 \\
(0.18)\end{array}$ & $\begin{array}{c}0.05 \\
(0.18)\end{array}$ & & & & \\
\hline Exchange rate: float & & $\begin{array}{c}-0.698 \\
(0.354)^{*}\end{array}$ & $\begin{array}{c}-0.628 \\
(0.345)^{*}\end{array}$ & & & & \\
\hline Exchange rate: free falling & & $\begin{array}{l}-0.246 \\
(0.18)\end{array}$ & $\begin{array}{l}-0.189 \\
(0.18)\end{array}$ & & & & \\
\hline Exchange rate: dual market & & $\begin{array}{l}-0.162 \\
(0.38)\end{array}$ & $\begin{array}{l}-0.16 \\
(0.37)\end{array}$ & & & & \\
\hline $\begin{array}{l}\text { Exchange rate: managed float, float, free } \\
\text { falling or dual market }\end{array}$ & & & & $\begin{array}{l}-0.134 \\
(0.17)\end{array}$ & $\begin{array}{l}-0.078 \\
(0.16)\end{array}$ & & \\
\hline Exchange rate: float & & & & & & $\begin{array}{l}-0.068 \\
(0.12) \\
\end{array}$ & $\begin{array}{l}-0.048 \\
(0.12) \\
\end{array}$ \\
\hline Exchange rate: intermediate & & & & & & $\begin{array}{l}0.033 \\
(0.18) \\
\end{array}$ & $\begin{array}{l}0.053 \\
(0.17) \\
\end{array}$ \\
\hline Log GDP / capita [10,000US\$] & & & $\begin{array}{c}0.283 \\
(0.161)^{*}\end{array}$ & & $\begin{array}{c}0.328 \\
(0.170)^{*}\end{array}$ & & $\begin{array}{c}0.365 \\
(0.157)^{*} \\
\end{array}$ \\
\hline Constant & $\begin{array}{c}-0.794 \\
(0.085)^{*} \\
\end{array}$ & $\begin{array}{c}-0.758 \\
(0.139)^{*} \\
\end{array}$ & $\begin{array}{c}-0.865 \\
(0.148)^{*}\end{array}$ & $\begin{array}{c}-0.77 \\
(0.146)^{*}\end{array}$ & $\begin{array}{c}-0.892 \\
(0.154)^{*}\end{array}$ & $\begin{array}{c}-0.776 \\
(0.105)^{*}\end{array}$ & $\begin{array}{c}-0.915 \\
(0.116)^{*}\end{array}$ \\
\hline $\begin{array}{l}\text { Observations } \\
\text { R-squared }\end{array}$ & $\begin{array}{c}42 \\
0.08\end{array}$ & $\begin{array}{c}39 \\
0.29\end{array}$ & $\begin{array}{c}39 \\
0.35\end{array}$ & $\begin{array}{c}39 \\
0.14\end{array}$ & $\begin{array}{c}39 \\
0.22\end{array}$ & $\begin{array}{l}39 \\
0.1\end{array}$ & $\begin{array}{c}39 \\
0.22\end{array}$ \\
\hline
\end{tabular}

Standard errors in parentheses, * significant at $10 \%$

The dependent variable is a country-specific regression coefficient for a symmetric treshold AR process that characterizes the speed of convergence of the current account to its long run equilibrium

The exchange rate regime classifications used in columns 2-3 and 4-5 are based on Reinhart and Rogoff (2004). In columns 4-5, their last three classifications are combined. The exchange rate classifications in column 6-7 are based on Levy-Yeyati and Sturzenegger (2002) 